\title{
الاستفهام في رسائل الشريف المرتضى دراسة أسلويية
}

\section{م. سعاد بلديع مطير}

\section{المقدمة}

الحمد لله رب العالمين ، والصلاة والسلام على خير الخلق أجمعين سيدنا محمد بن عبد اله ، وعلى الطى

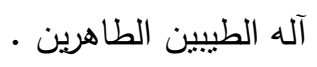

فإن رسائل الثريف المرتضى ، هي احدى مؤلفات علم الهدى أبي القاسم : علي بن أبي

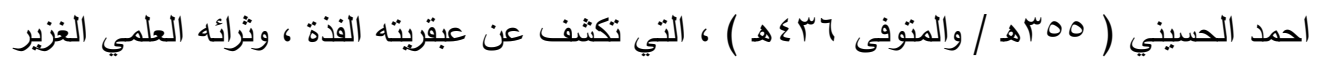

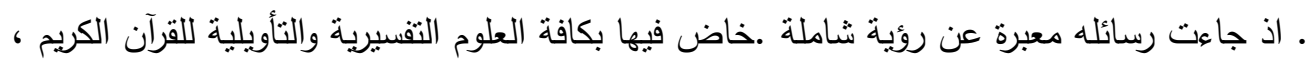
والأحاديث النبوية الثريفة ، فضلاً عن الموضوعات الفقهية ، والأصولية، والعقائدية ، والأدبية .

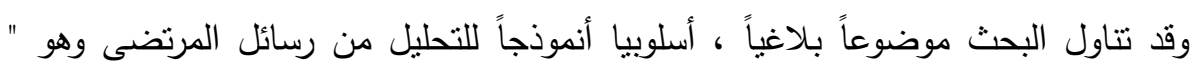

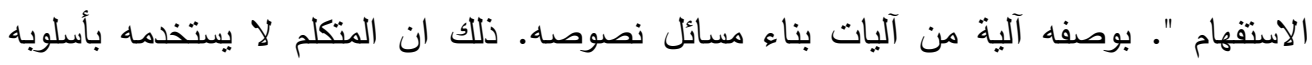

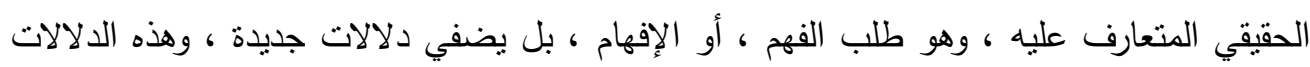

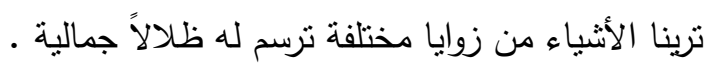

وقد كانت الأسلوبية بمنهجها التحليلي المنهج المتبع في البحث ـ كونها الوسيلة الأساس ، التي

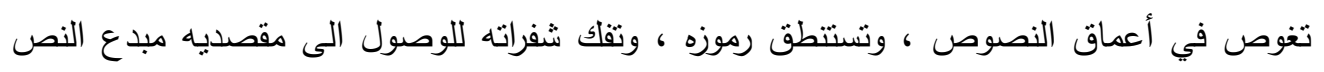

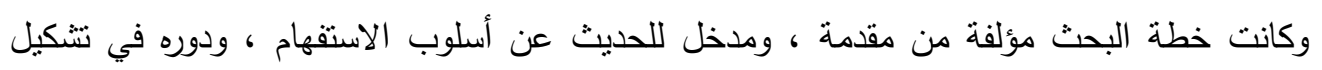

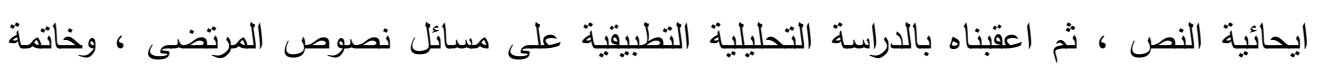

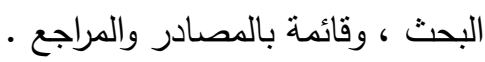

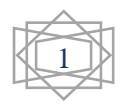


وأخيرا فإننا نود ان نشير اننا لا ندعي الكمال في هذا البحث ، وحسبنا إننا اجتهنا ، وما توفيقنا إلا باله عليه توكلنا ، واليه ننيب .

\section{المبحث الأول}

\section{أسلوب الاستفهام}

أسـلوب الاسـتفهام ، هـو أحــــ المهيمنـات الأسـلوبية ، المعتمــدة فـي الهندســة البنائيــة للنّص • وقد حدد الاسـتقهام بأنّهـ " طلب العلم بشـيء لـم يكن معلومـاً مسن قبـل ، وهـو اسـتخبار

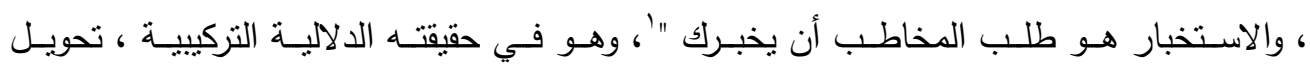

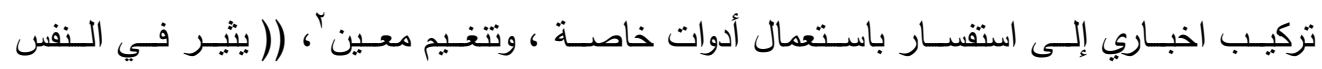

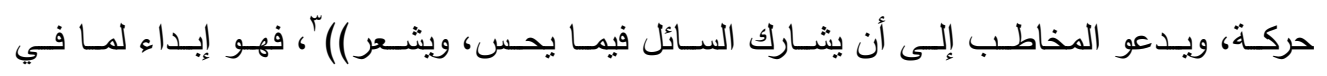

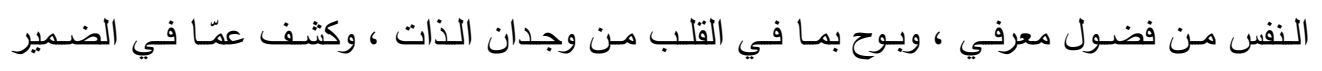

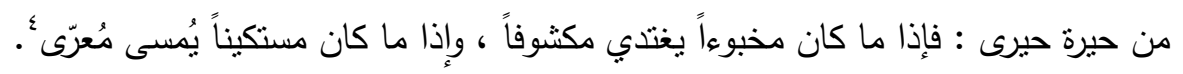

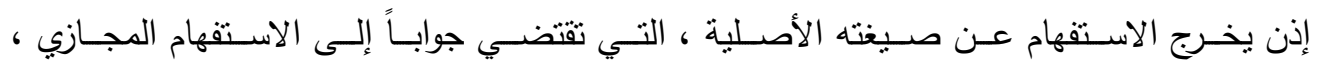

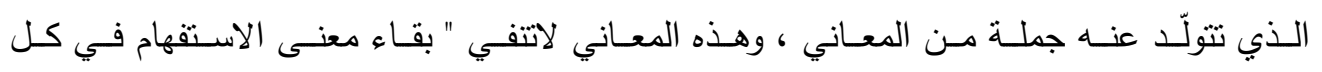

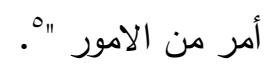

وتأكـدت أهميـة هـذا المنحسى ألتشـاؤلي عنـــ الثــريف المرتضـى ، بوصـفه مهيمنـاً أسـلوبياً

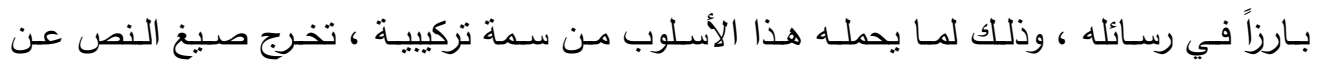

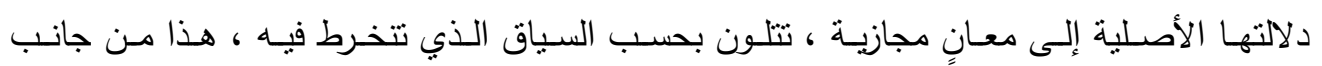

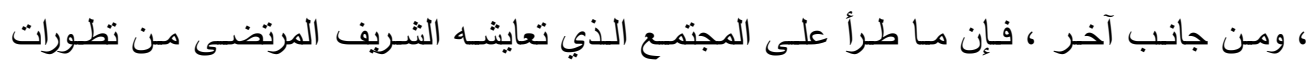

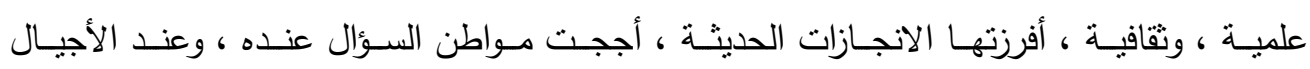

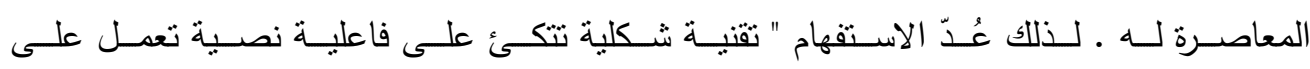

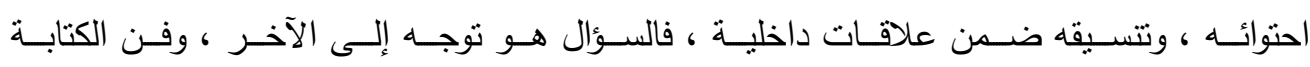

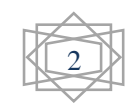


استحضـار لــللك التوجـهـ ، وهـا التوجـه لـيس مجـرد سـمات شـكلية بـل هـو استحضـار وإنتـاج

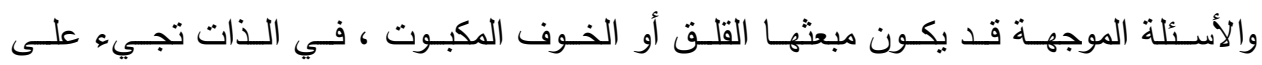

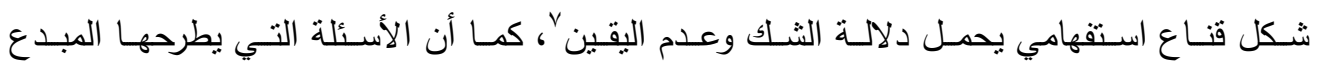

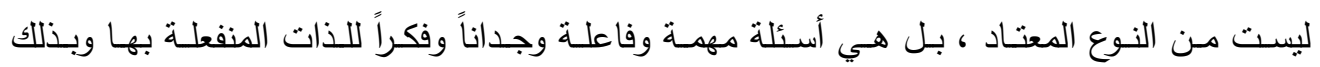

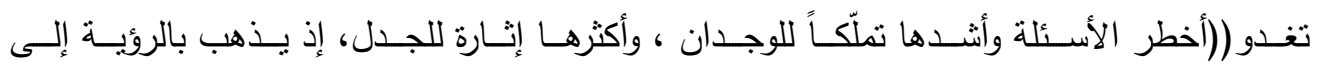

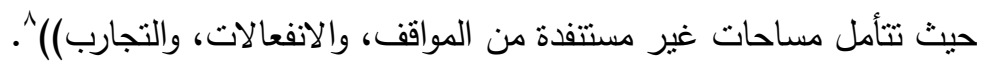

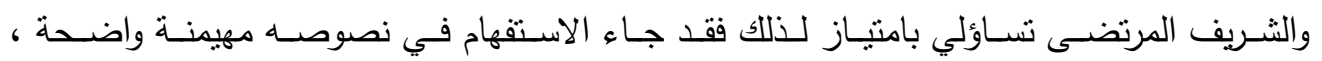

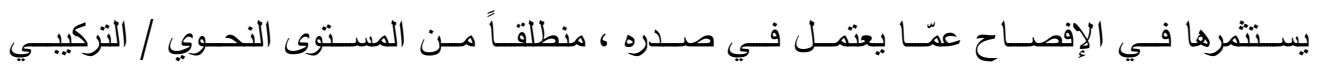

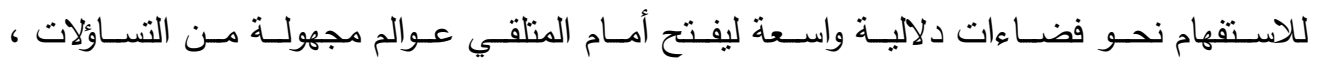

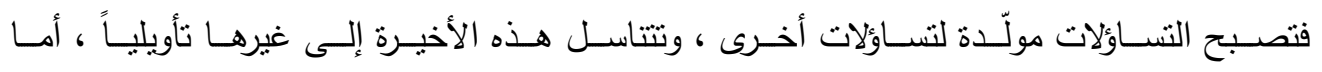

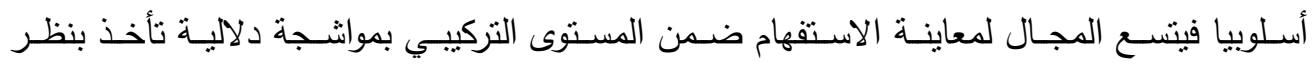

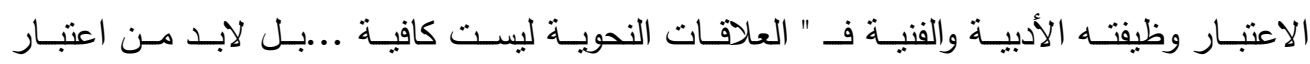

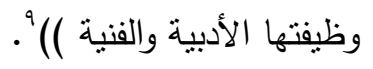

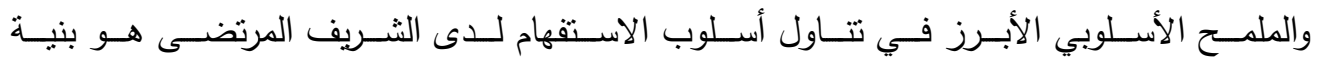

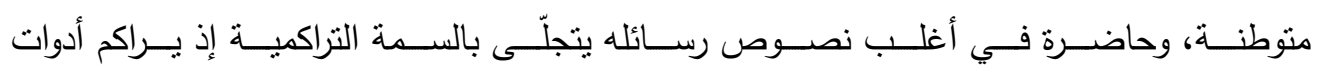

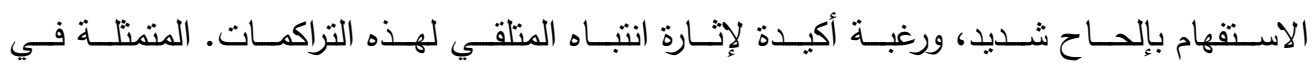

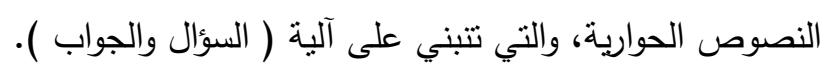

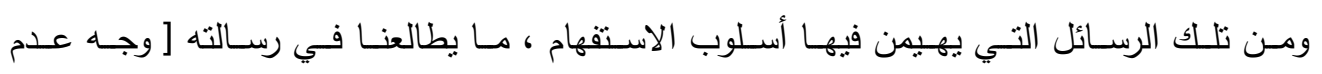

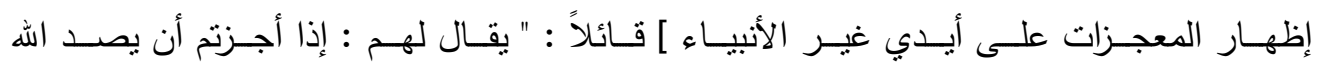

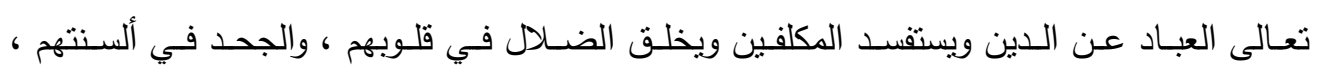

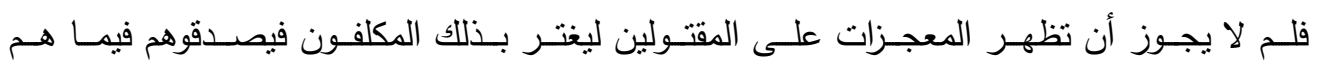
فيه كاذبون ؟ 


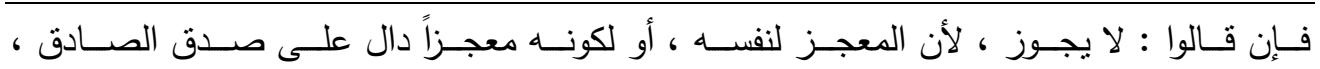

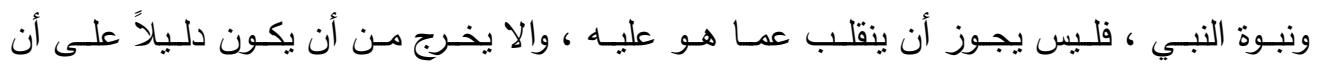
فاعله قادر ·

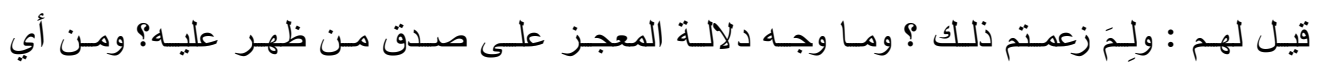
وجه أثبه ما ذكر عليه.

فإن قالوا: بينوا أنتم وجه دلالة ما ذكرناه على ما زعمتم أنه دليل عليه .

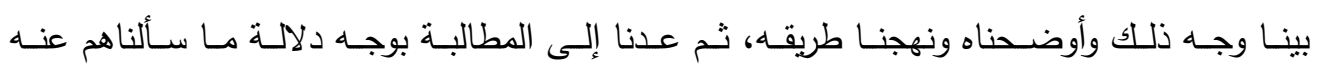
على المسامحة دون المضايقة.

فإن قـالوا: لأنـا رأينـا دعـاء كل من كذب في ذللك بسـمع ، والعلم عند مسـألته ، لا يقع فعلمنـا

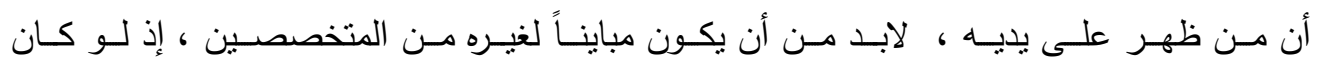

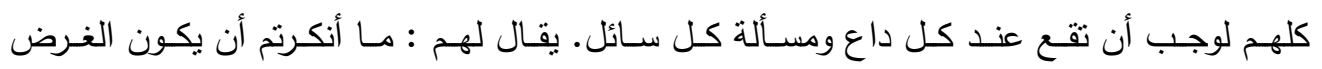

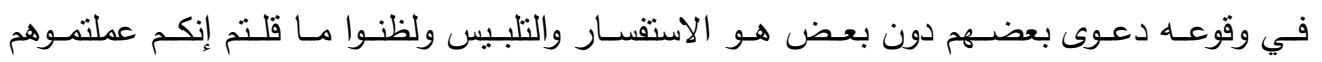

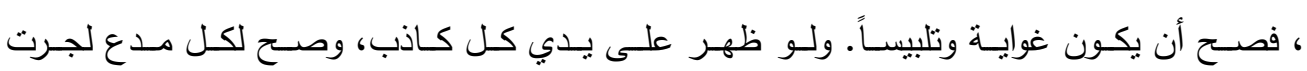

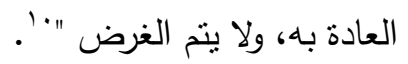

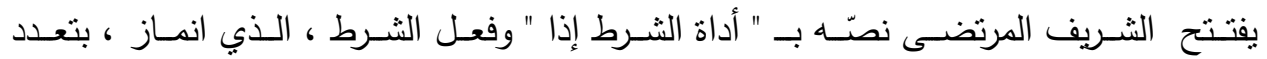

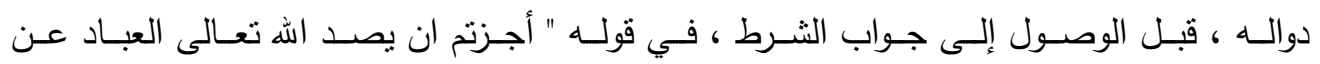

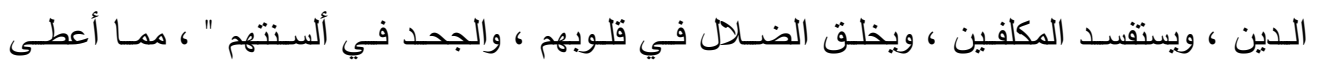

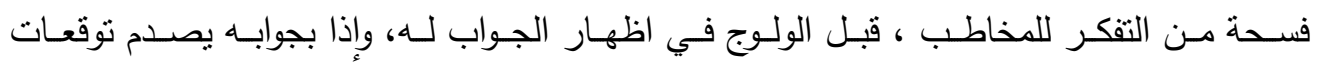

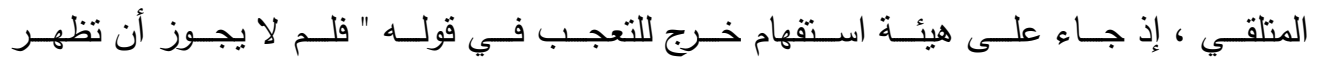

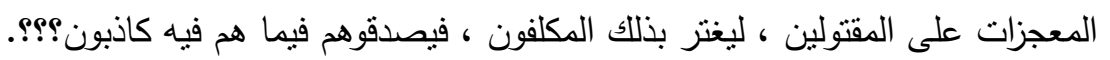

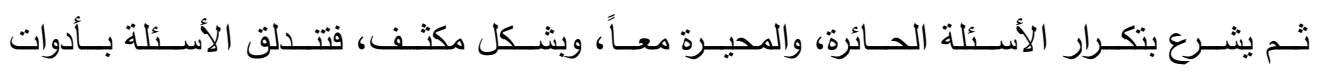

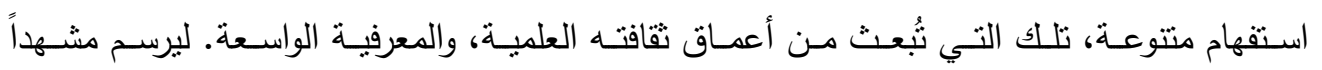

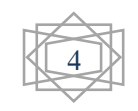




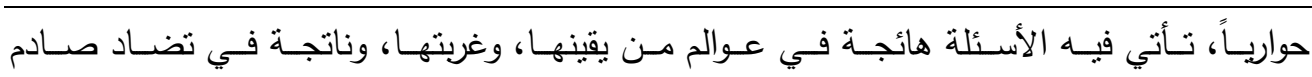
ومؤثز تركيبياً ودلالياً بينه وبين المعارضين، إذ نحوي على هانَ النص بأكمله.

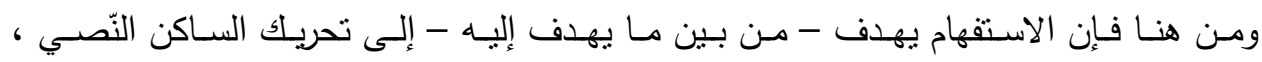

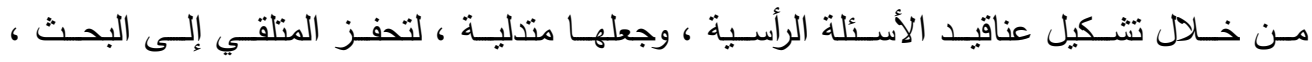

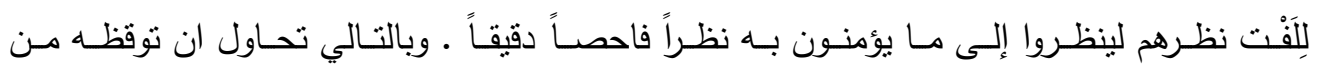

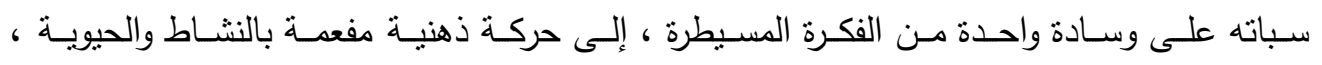

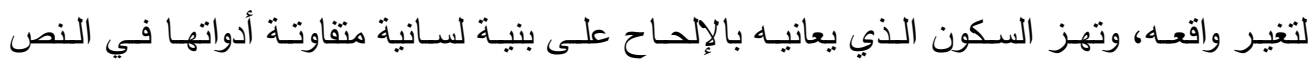

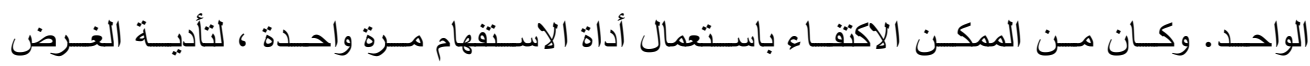

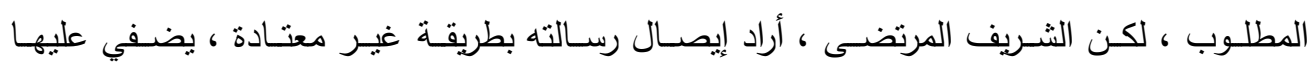
سمة الانزياح عن المألوف لجعلها أكثر تأثيراً في ذهن الهن السامع والمنلقي.

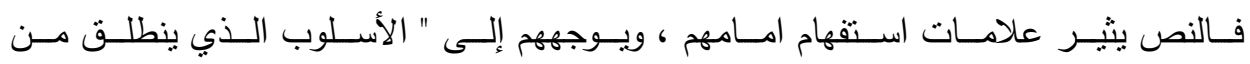

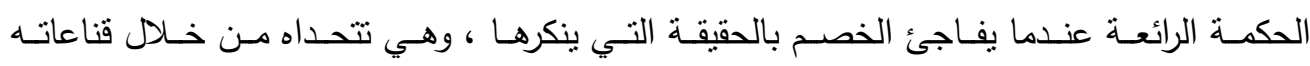

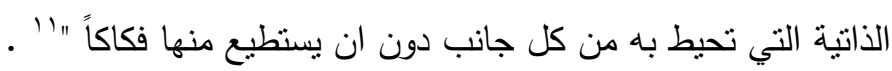

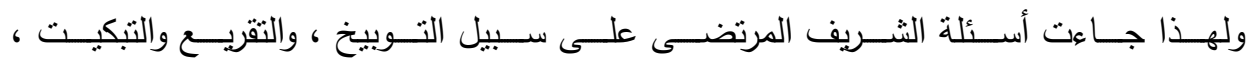
والإنكار ، والاحتجاج ، كوصف لقدرته على ابطال ادعاء الآخرين ، واستتكاراً لأفعالهم.

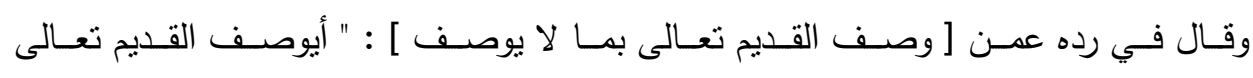
بالقدرة على ان يظهر المعزات على أيدي الكذابين ؟ فإن قالوا : لا يوصف بالقدرة على ذلك . قيل لهم : فهل يقتضي ذلك تعجيزه تعالى وخروجه عن صفة من صفات ذاته ؟

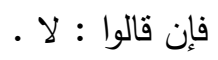


قيل لهم : فلم تتفروا من شيء أحلتم وصفه بالقدرة على وجه دون وجهه ، وذلك أن كذب هذا

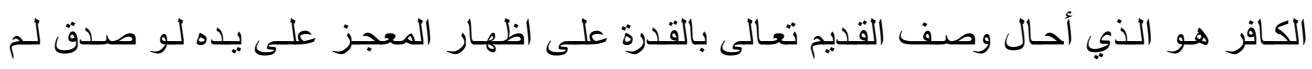

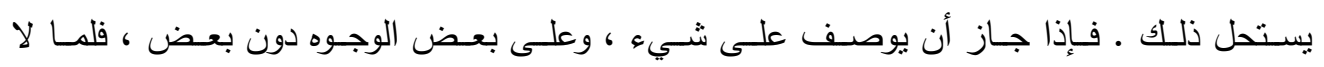

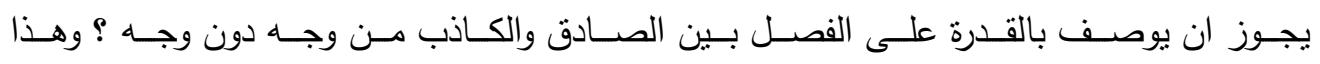

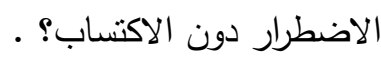

وان قالوا : ان القديم تعالى موصوف على اظهار المعزز على أيدي الكذابين . قيل لهم: فما الذي يؤمن من فعله ؟

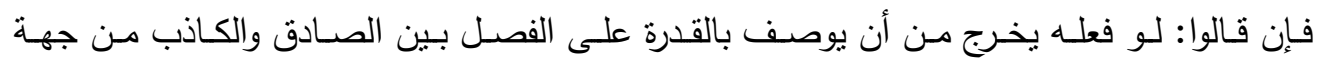
الدليل . قيل لهم: فكأنه يقدر أن يخرج نفسه من أن يكون قادراً على ما يصح وصفه بالقدرة عليه. قالوا : نعم .

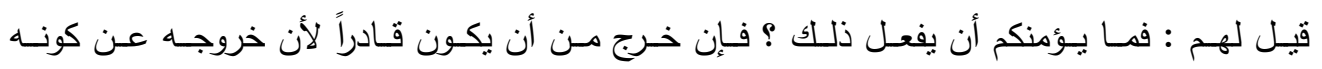

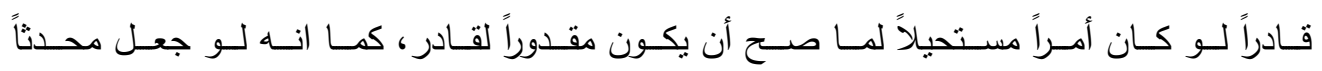

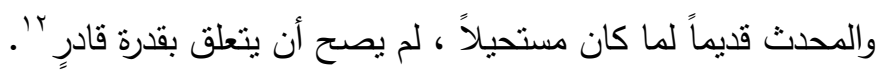

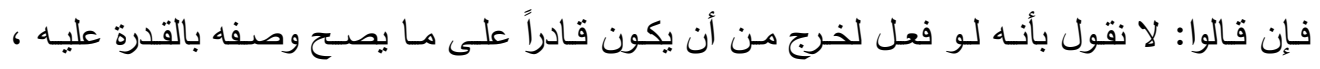

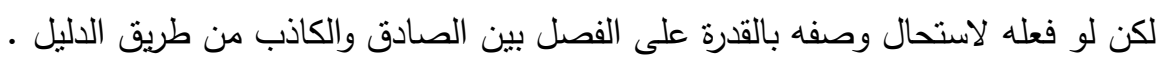

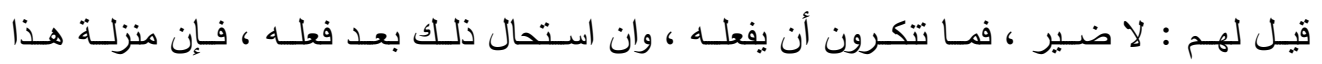

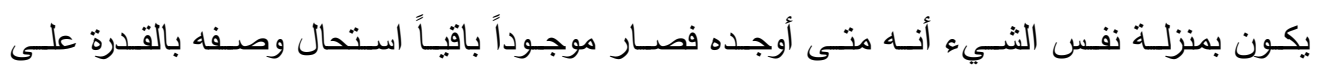

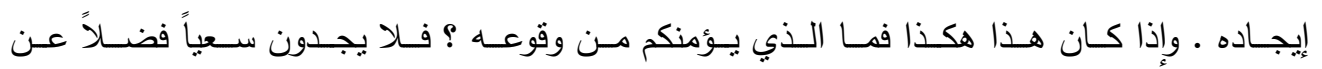




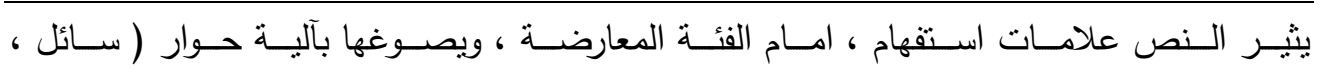

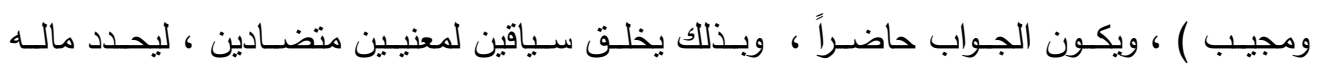
، وما لهم من أفكار ورؤى .

فيـؤدي الأســلوب الاســفهامي الوظيفـة التعبيربــة ، والإدراكيـة الناتجــة عـن تــــاعيات الســياق القاضـي بتكـوين حلقـة كلاميـة ديناميكيـة منواصـلة بـين منشـئ الـص ، والمتلقـي بفعـل عمليتي الإثـارة والاسـتجابة ـ ليعبـر الثـريف المرتضـى عـن مقصـديته ، بإيجـاد علائست متســاوقة بـين

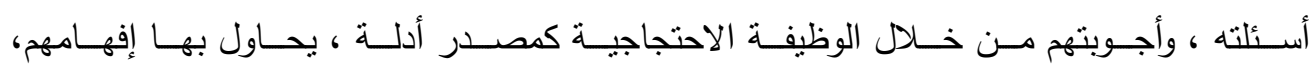

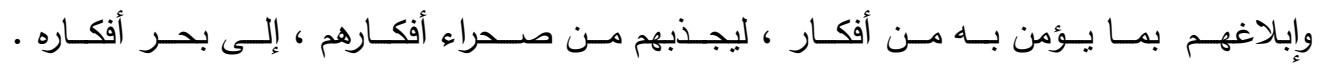

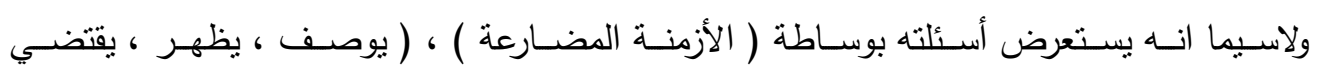

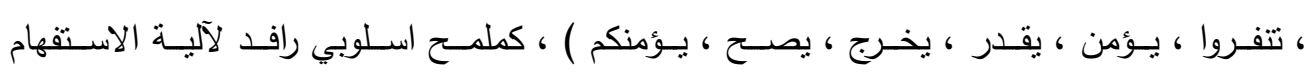

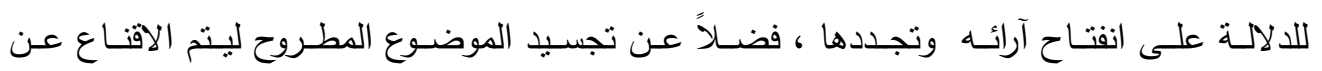
طريـق استقصـاء وصـف حسالات عدة ، نظهـر فيهـا مقدرة الخـالق تعـالى .تتتهي بـالمتلقي إلى

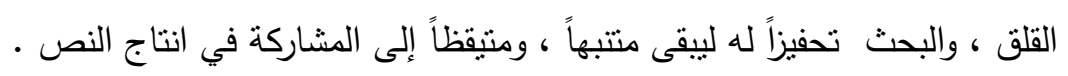

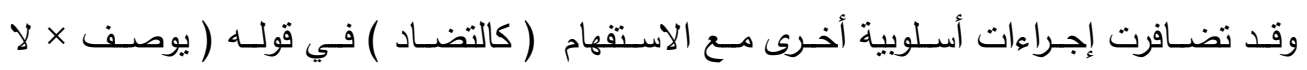

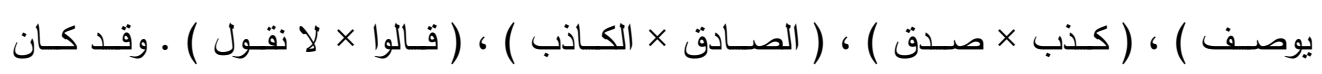

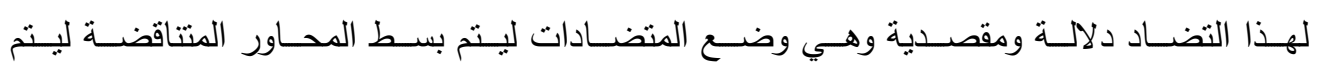

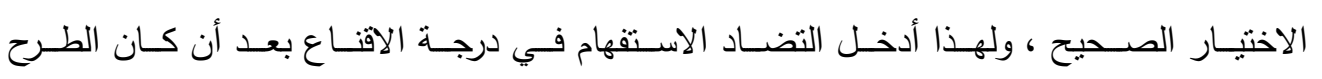
يسير نحو الاقناع ·

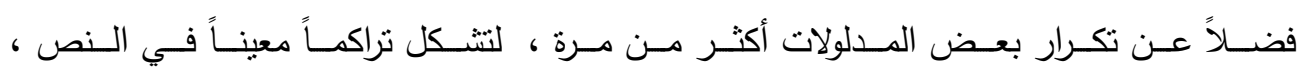

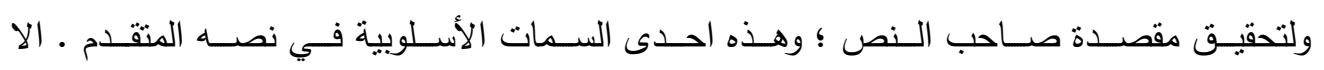

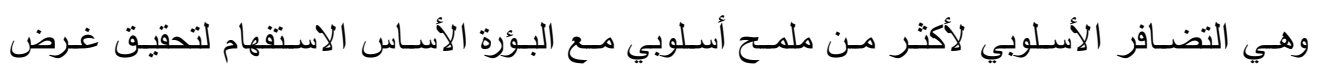

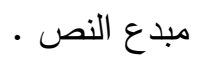

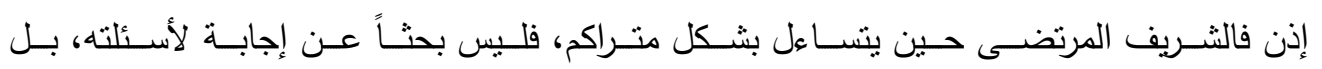

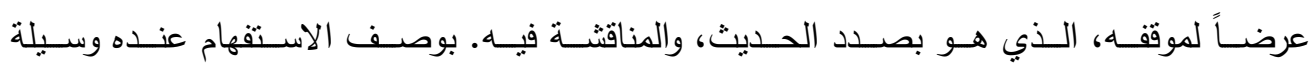




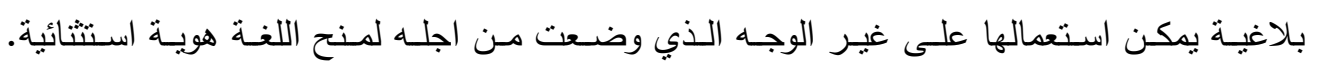

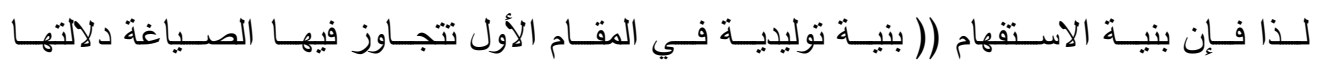

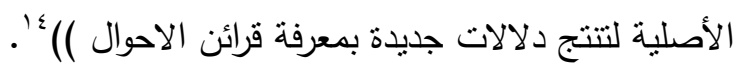

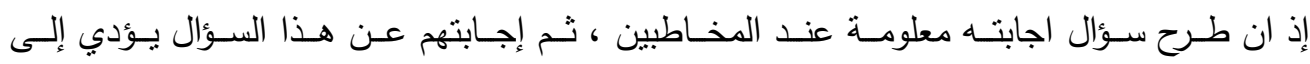

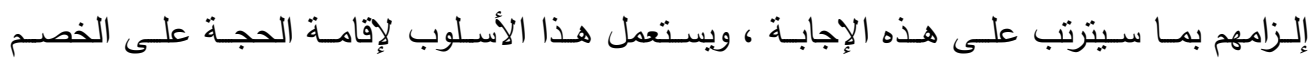
، وإقحامه .

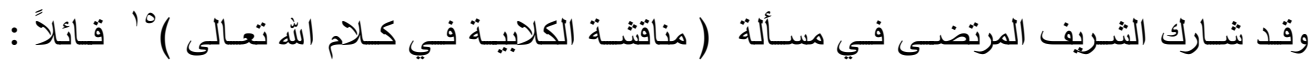

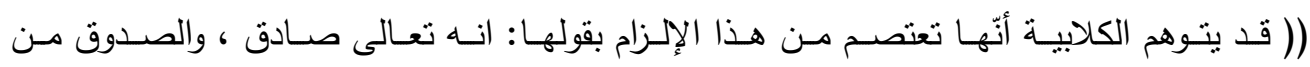

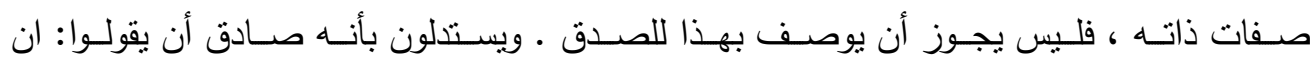

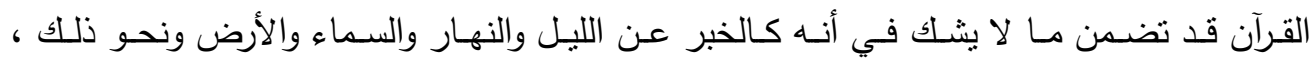

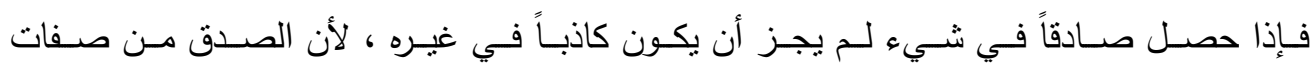
ذاته .

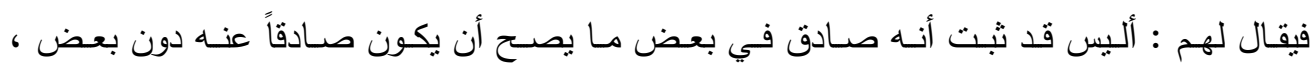

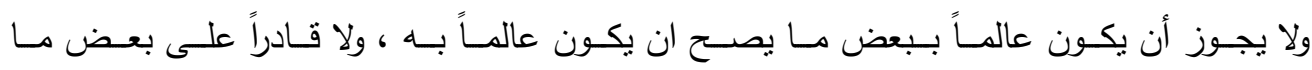

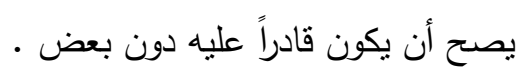

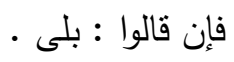

قيل لهم : فما أنكرتم أن كان يكون كاذباً في بعض ما يصح ان يكون صادقاً عنه ، وان لم يجب أن

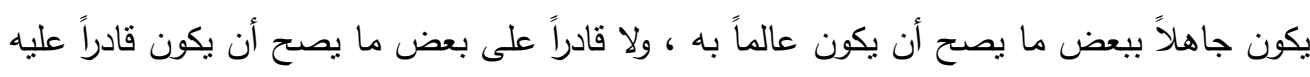

فإذا قالوا : هو صادق في جميع ما يصح أن يكون صادقاً عنه الا انه لم يحك ذلك لنا أو لم يفهناه

يقال لهم: خبرونا عن هذه الحكاية والإفهام أليسا من صفات فعله، ولا من صفات ذاته؟ 
قيل لهم : أهي في نفسها كلام واخبار ·

فإن قالوا : لا ـ.

قيل : فكيف تعلمون ان اله تعالى قد صدق في شيء ، وما يعني ذللك وما سمعتم كلامه ، وإنما

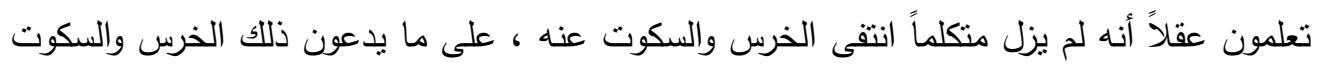

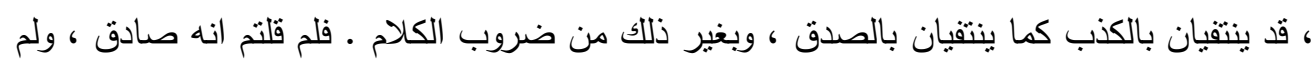

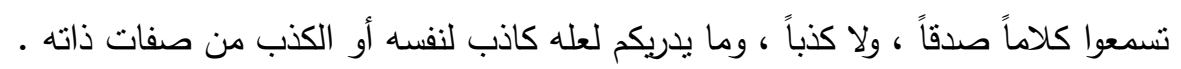

فإن قالوا: هذه الحكاية نفسها كلام.

قيل لهم: ومن المتكلم بها . - الما

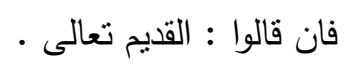

قيل لهم: يجوز أن يوصف بأنه متكلم من وجهين: من صفات ذاته ، ومن صفات فعله . فإن قالوا : نعم . قيل لهم : فما أنكرتم أن يكون صادقاً من صفات ذاته كاذباً من صفات فعله. فإن قالوا: لو لزمنا هذا للزمكم ان يكون عالماً لنفسه جاهلاً بجهل محدث .

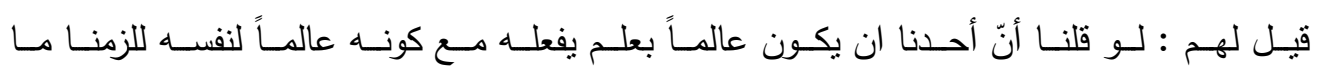

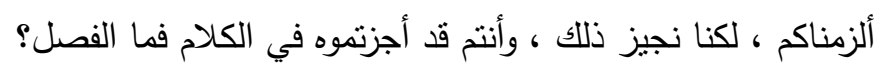
فإن قالوا : إن المتكلم بهذه الحكاية غير اله . 
العــــــد الثـــامن عشــر

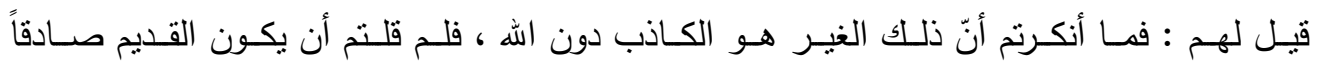

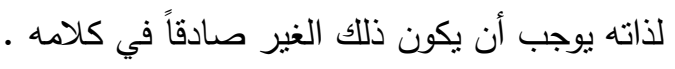

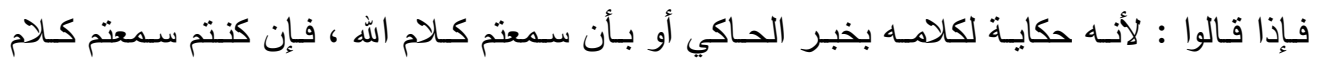

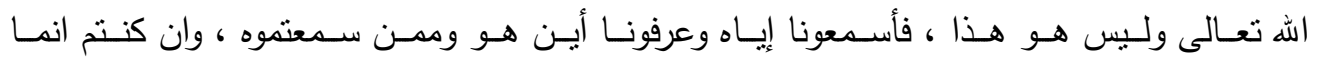

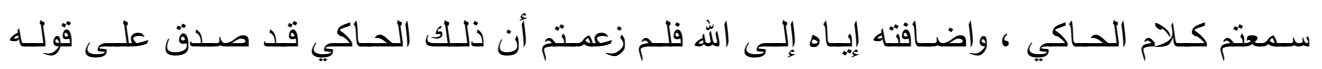

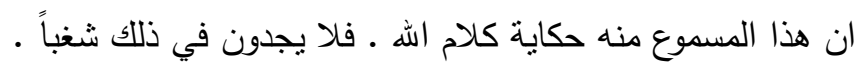

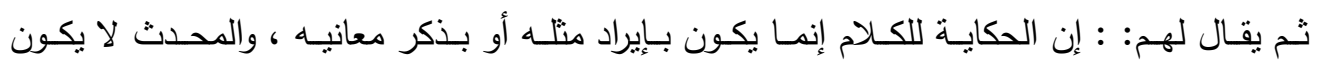

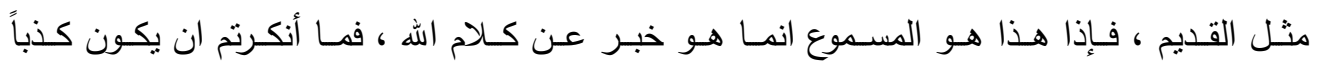

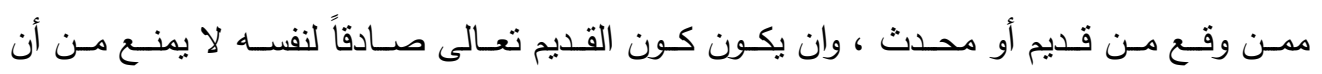
يكون هذه كذباً .

فإن قالوا : ليست بكلام أصلاً .

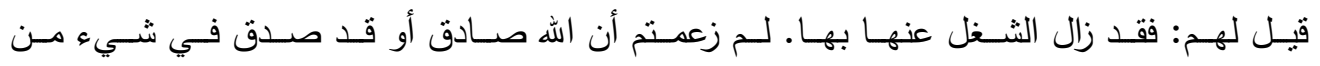

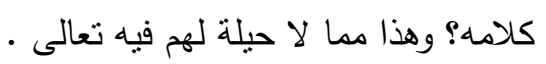

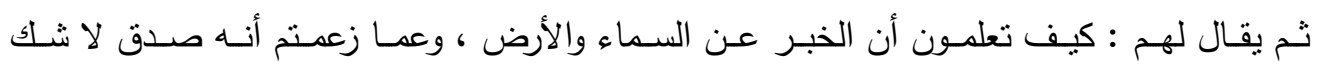

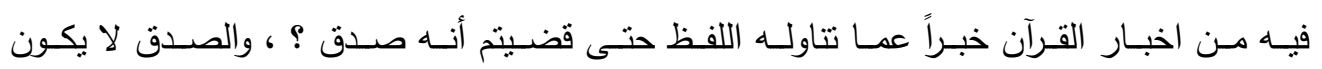

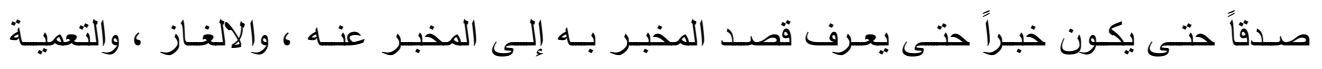

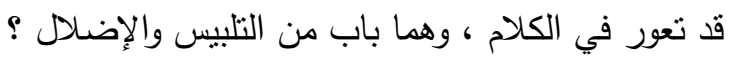

فلم لا يجوز أنْ تكون ألفاظ القرآن كلها خارجـة عن تلك الوجوه ، فـلا يكون فيها شـيء قصــ

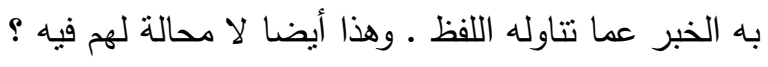

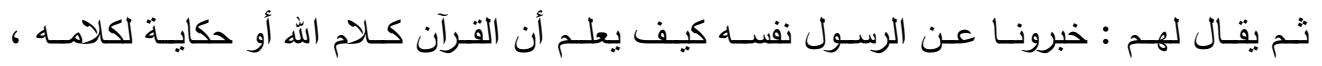

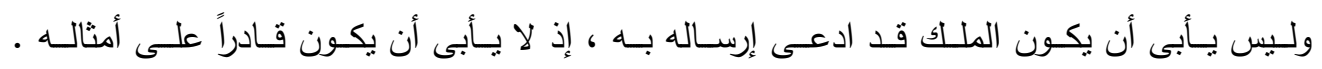

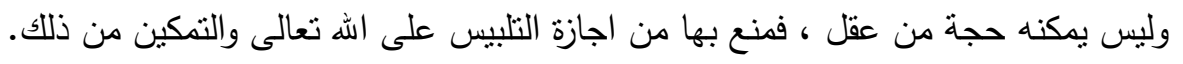




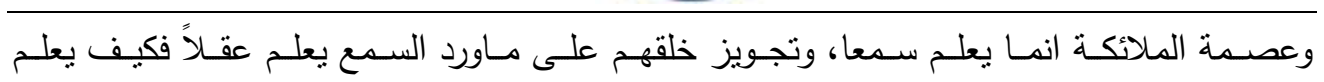
أنه رسول اله ؟

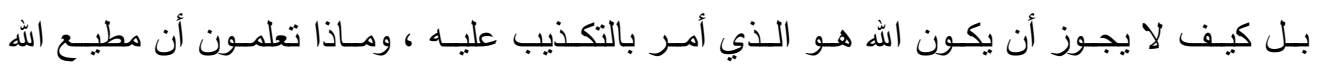

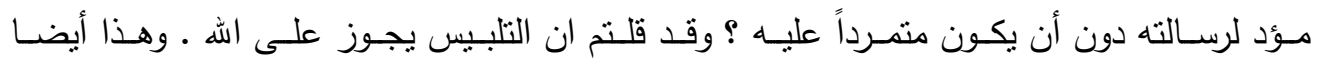
مما لا حيلة لهم فيه.

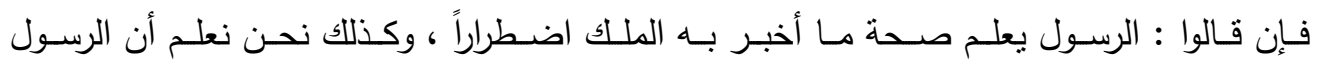

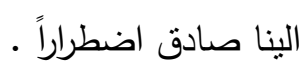

قيل لهم : أفصح أن يعلم ذلك استدلالاً ؟

فإن قالوا: نعم . طولبوا بالحجة وليس إلى ذلك طريق فإن قالوا : لا .

قيـل لهم: قد صـرتم إلى مـا كنتم تمتتعون منـه مـن أنـه لا يوصف القديم بالقدرة على أن يـلـل على صدق الصادق.

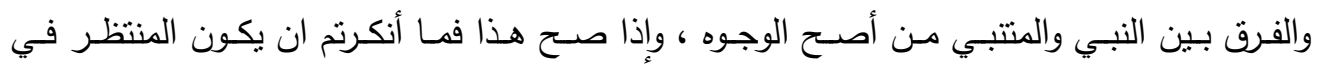

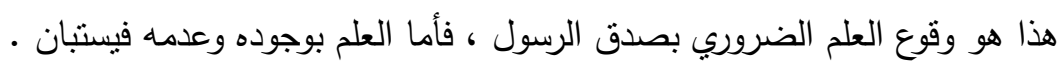
فإن قالوا : هو كذلك .

قيـل لهـم: فظهـوره الآن على الكـاذبين أجـور مــا يكـون إذا كـان لا معتبـر بــه وان يوجـب الله علينا تصديق من لا علم له.

فإن مـروا على ذلـك قيـل لهم : فلـيس لهم للرسـل بمعجزة حجـة ، وإنمـا يـدعى على ضـمائر

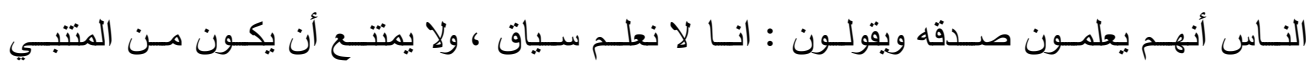

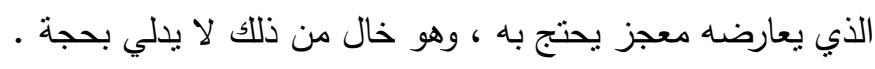
وهذا خروج من جميع الأديان والملل، ولا مذهب لكم عنه إلا بترك مذهبكم. 


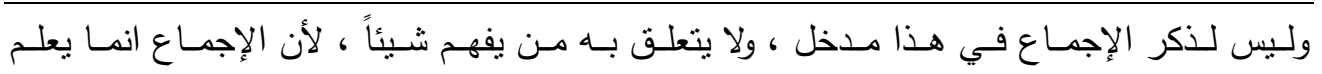

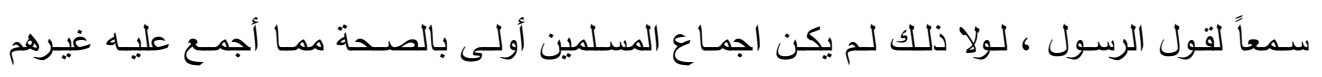

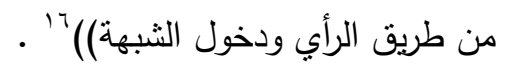

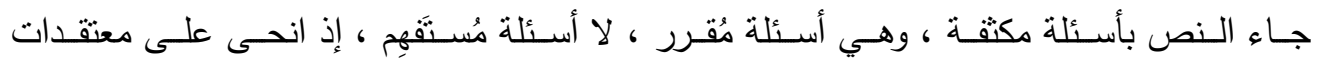

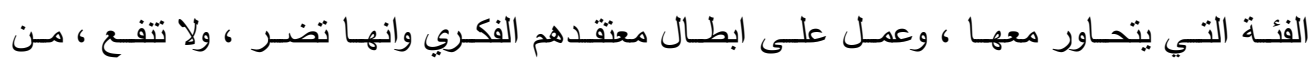

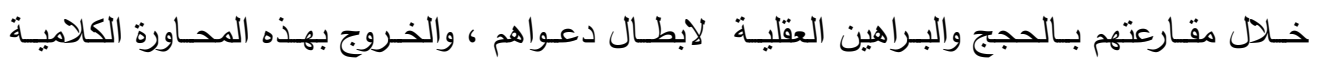

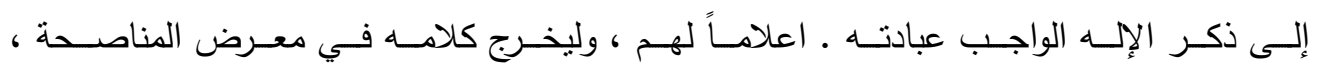

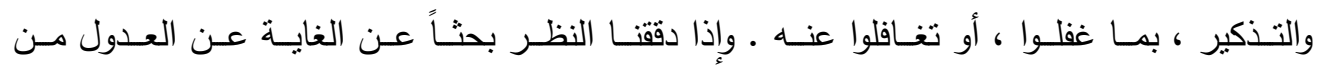

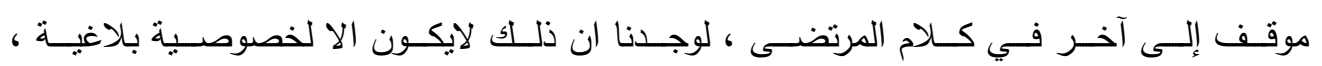

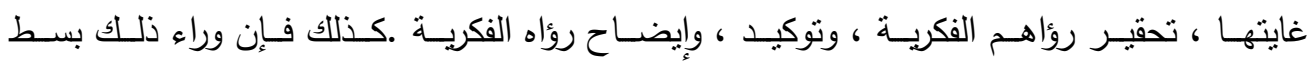

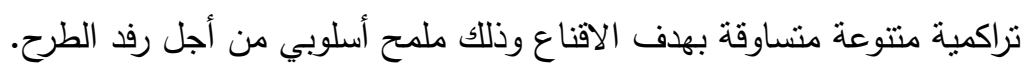

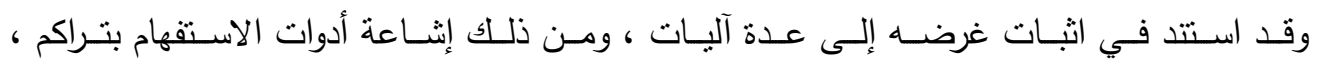

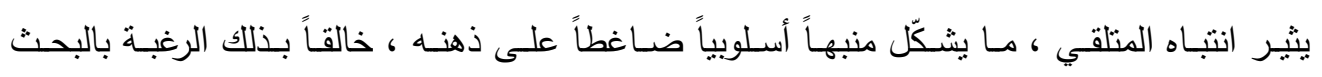

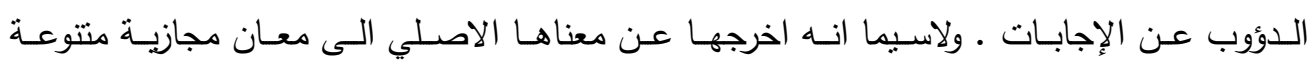

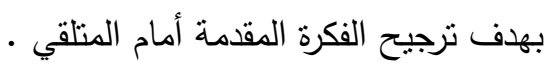

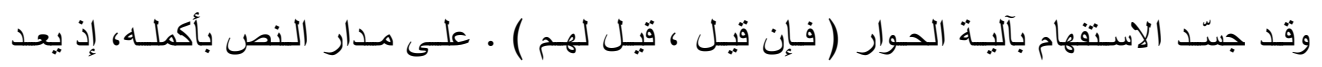

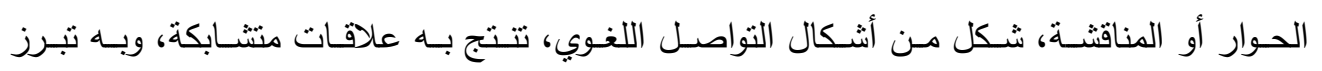

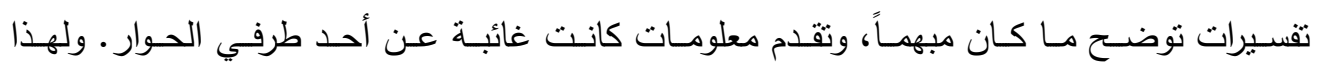

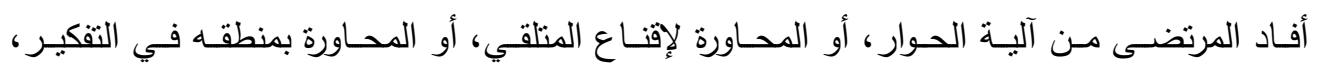

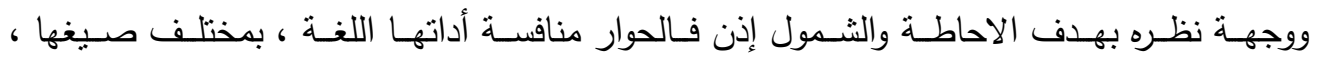

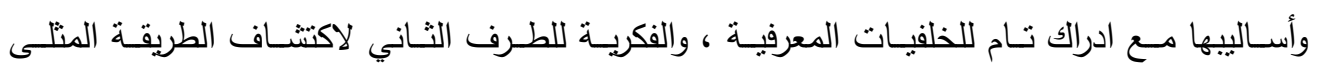

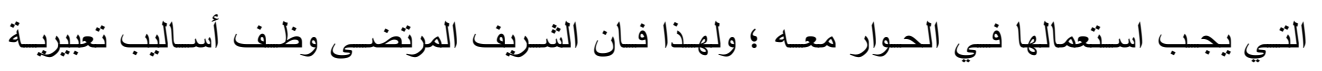

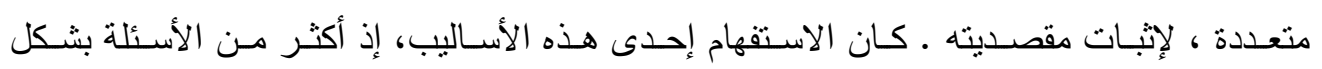

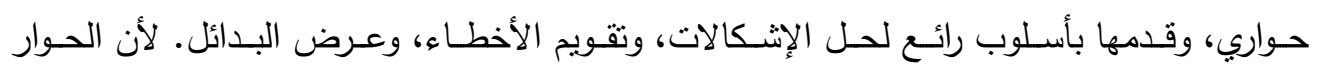




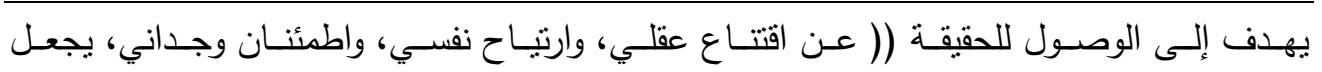

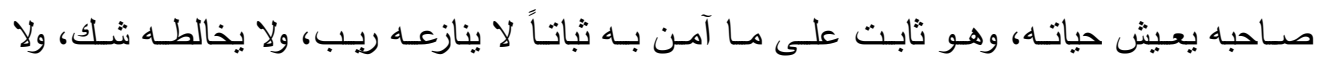

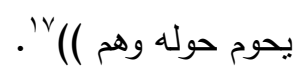

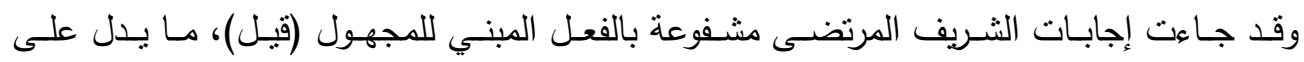

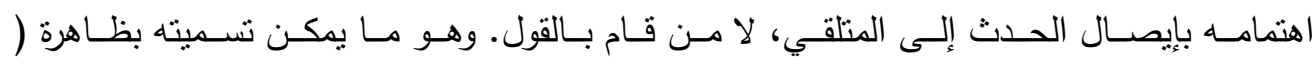
ازدواج الاستفهام بالحبك الحواري ).

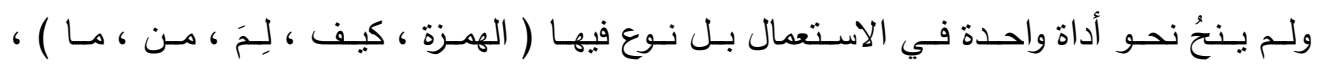

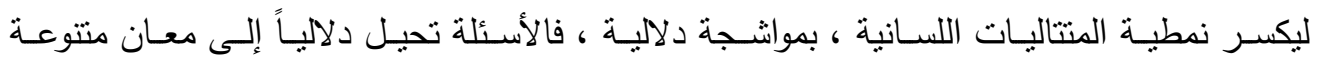

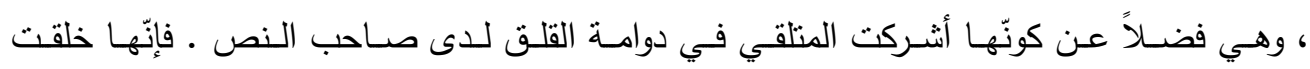

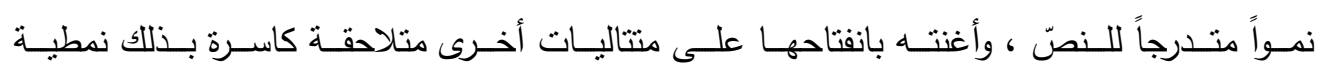

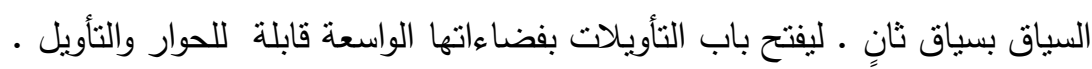

ومـن الملامـح الأسـلوبية التـي تـآزرت ، مـع الاسـتقهام لتحقيـق مقصــيته ، أسـلوب ( التضــاد )

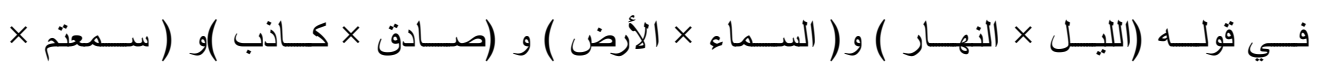

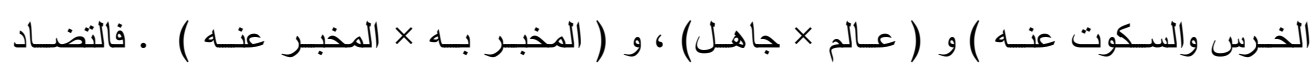

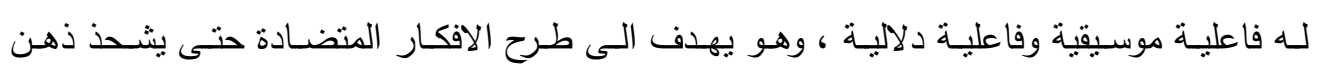

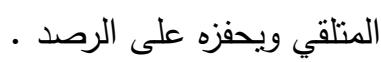

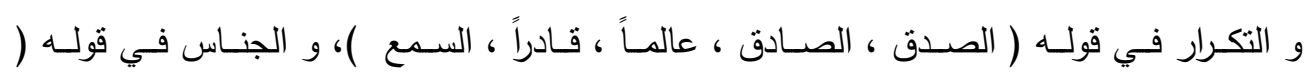

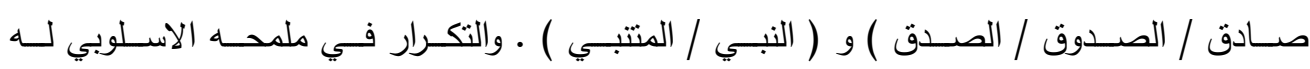

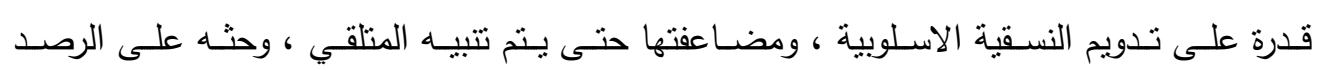

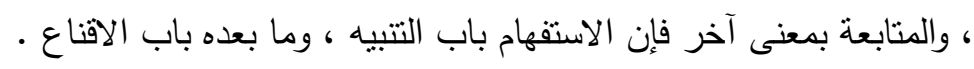

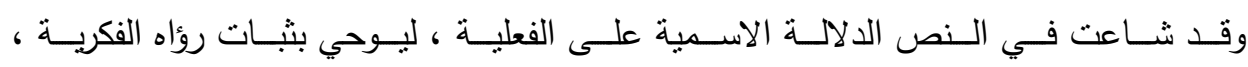

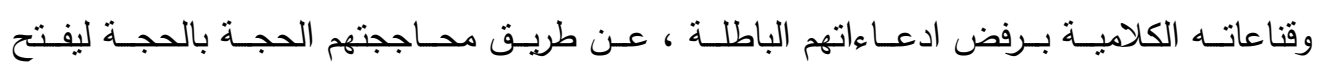


للمتلقـي بـاب التأمـل فيهـا ، والانسـحاب مـن سـاحات فكـرهم المضـطرب إلـى ســاحات فكـره

\section{مجلــــة كليـــة التربيــة}

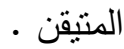

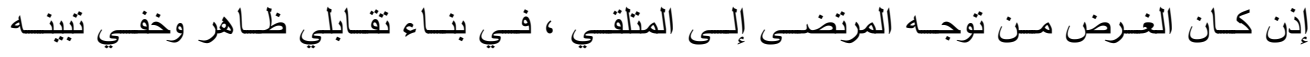

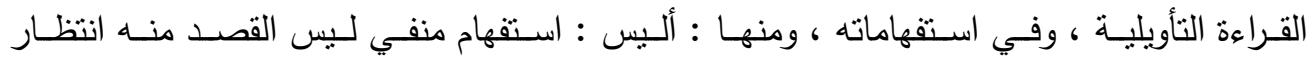

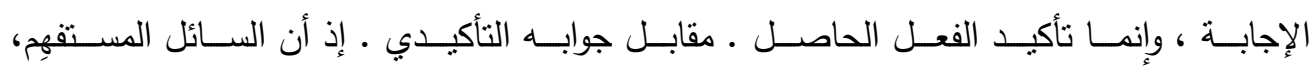

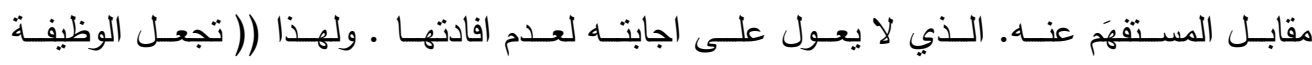

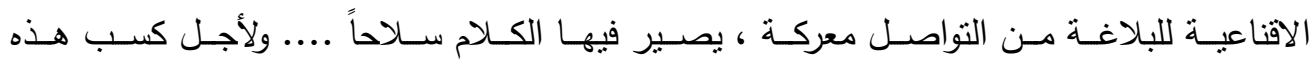

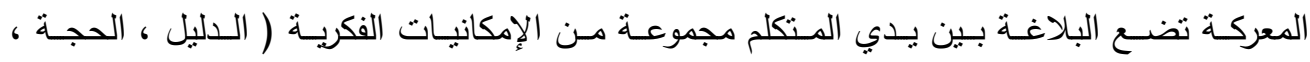

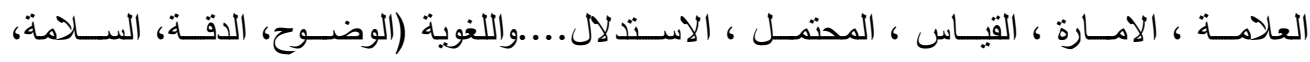

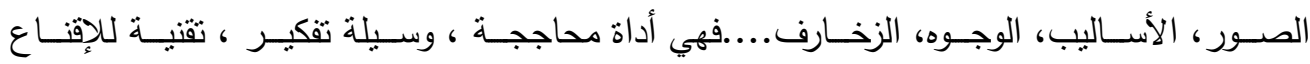

وقـال فـي مناقثــة ( مســألة فـي ارث الأولاد ): " يقـال لهـم: خبرونـا عمـن خلـ أولاد ابـن وأولاد

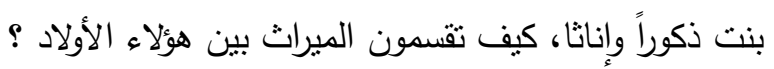
فإن قالوا: للأكر مثل حظ الأنثيين. قلنـا : فبـأي حجـة فعلتم ذللك ؟ فـلا وجـه لهذه القسـة الا قولـه تعـالى " يوصيكم الله في أولادكم

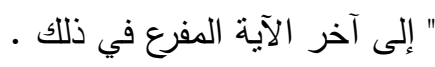

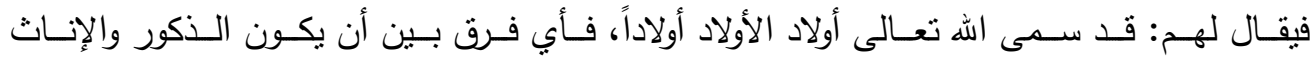

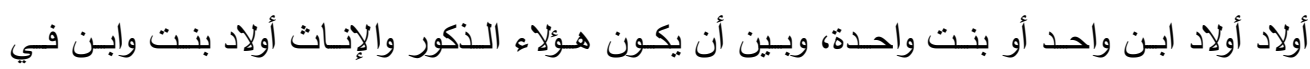
تتاول الاسم لهم.

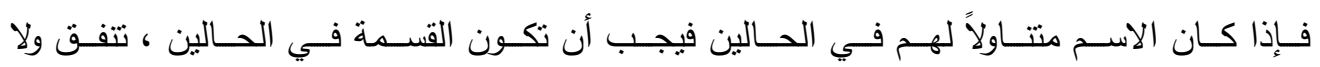
تختلف ، ويعطى أولاد البنـات الـذكور ، والإنـات وأولاد البنـين الـكور والإنـاث للذكر مثل حــ الأنثيين ، فلا يخالف حكم الآية في احد الموضعين، وتتاول الآية لهما تتاولاً واحداً . 
فإن قالوا: يلزمكم أن تورثوا أولاد الأولاد مع الأولاد لتتاول الاسم للجماعة.

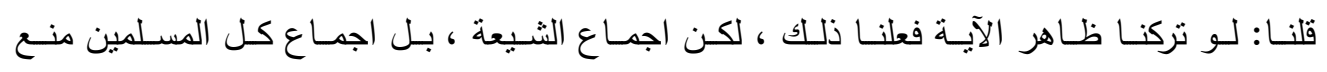

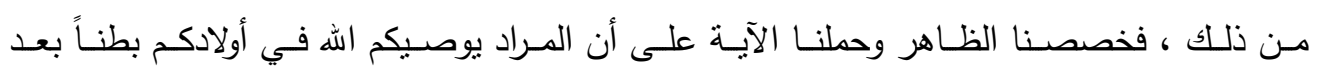
بطن

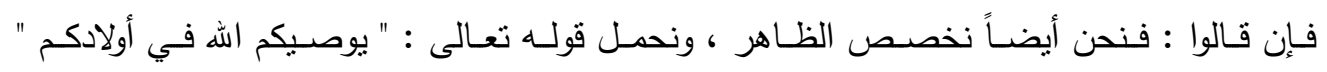

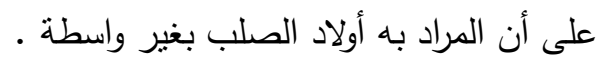

قلنا : تحتاجون إلى دليل قاطع على التخصيص كما فعلنا . فإن قالوا: أجمعت الأمامية عليه.

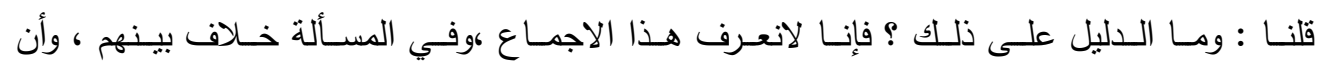

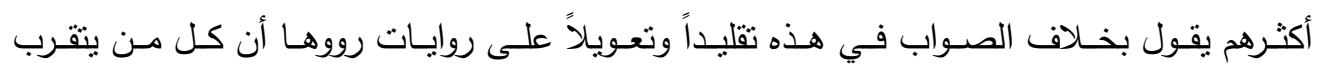

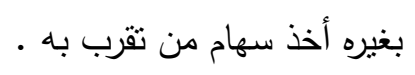

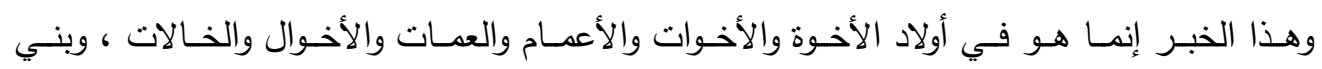

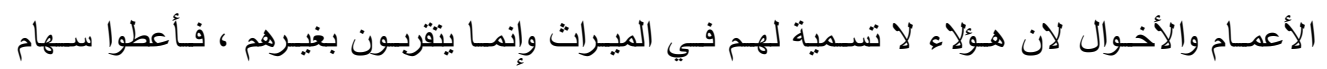
من يتقربون به .

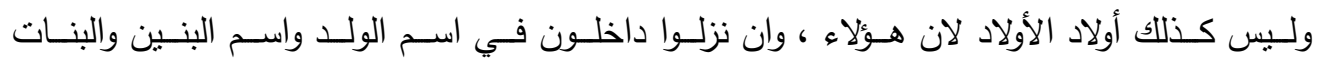

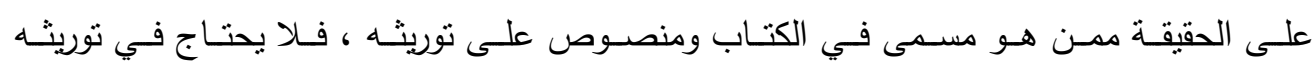

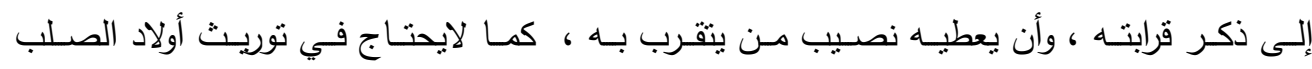

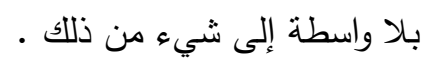

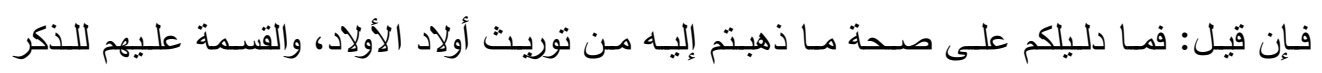
منل حظ الأنثين. 


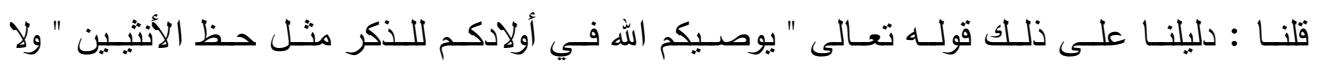

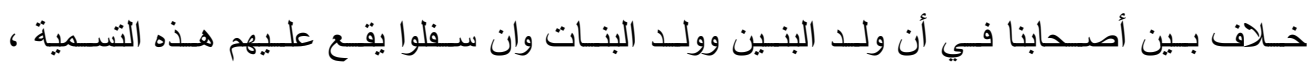
وتتاولهم على سبيل الحقيقة .

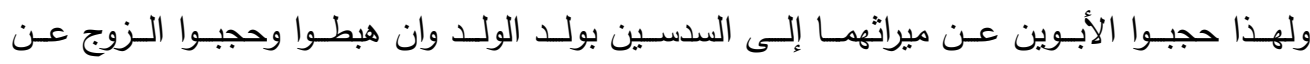

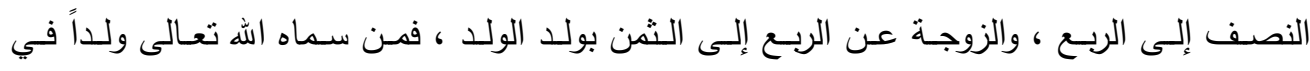

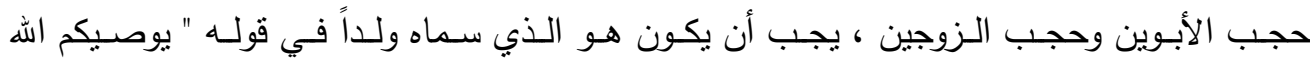

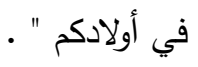

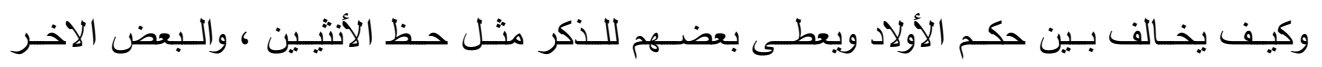

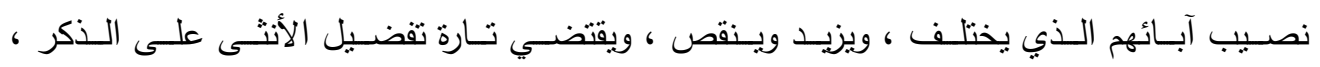

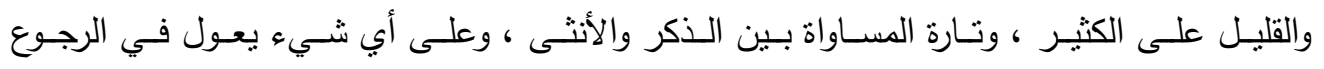

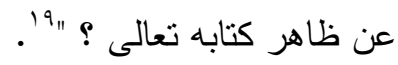

يحوي النّص أسئلة متعددة، معبرة عن سؤال جوهري، يمثل بؤرة النص، ويمكن تلخيصـه بـ "

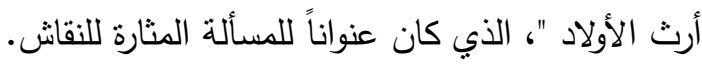

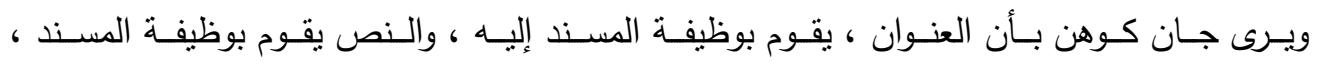

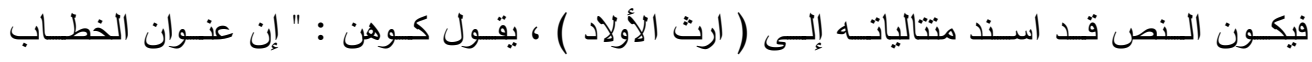

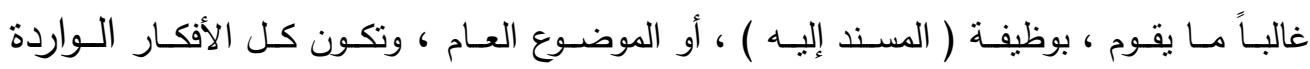

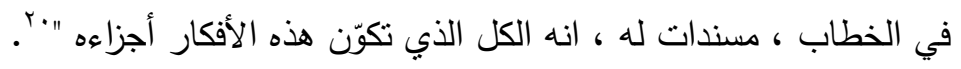

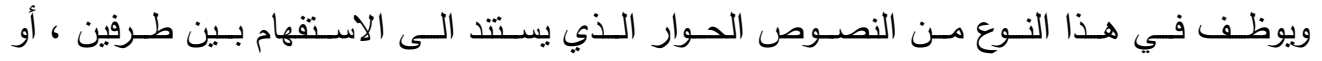

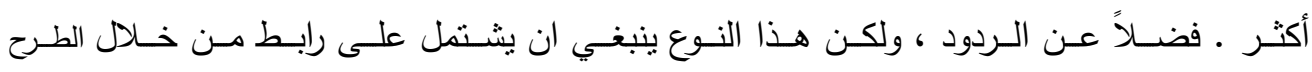

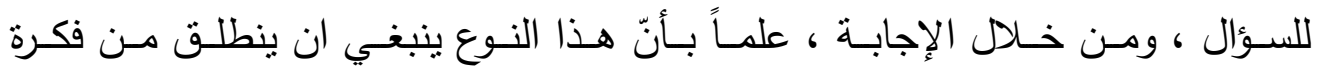

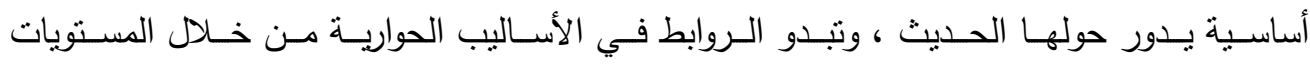

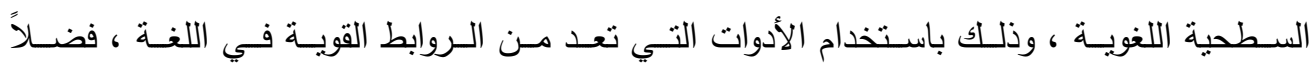

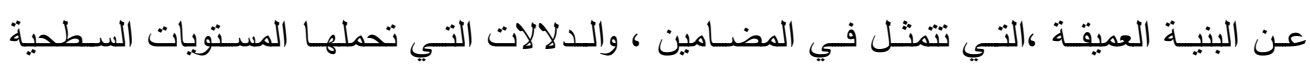




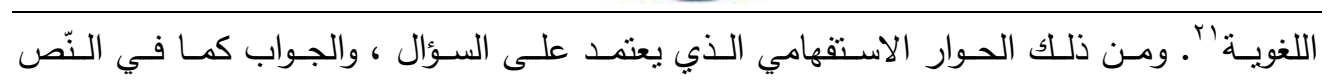

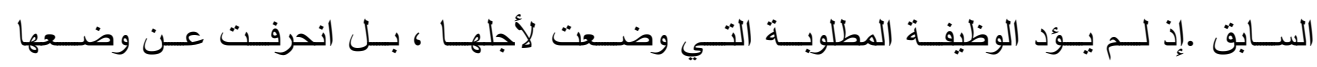

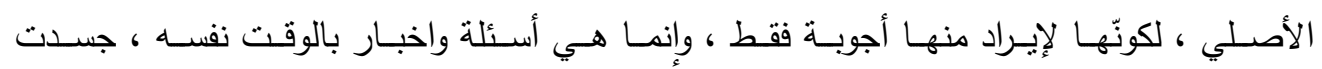

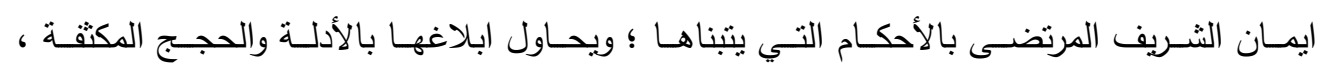

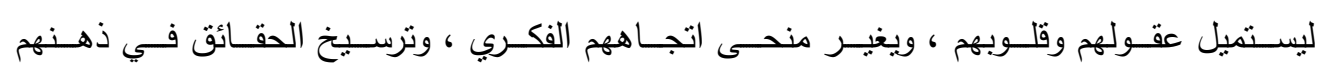

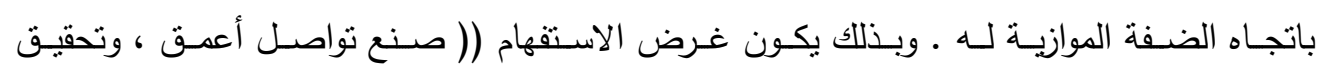

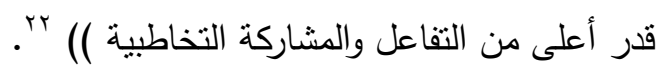

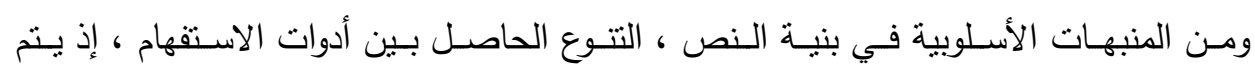

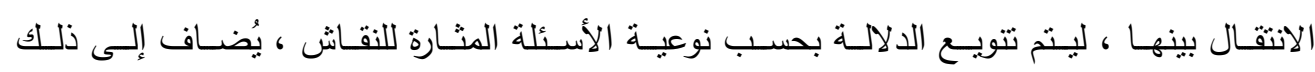

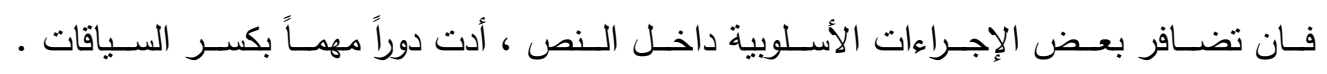
ضاعفت من تحفيز المتلقي تجاه النّص ومتابعة دواله ، ومدلولاته.

وسـألوا الثـريف المرتضـى عـن مسـألة ( عدم جـواز اضـلال اله تعـالى عـن الـدين ): لـو جـاز

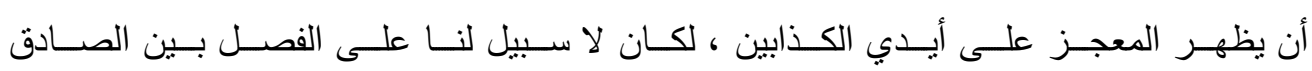

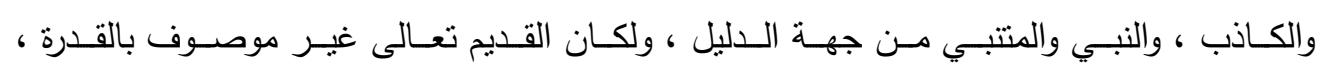

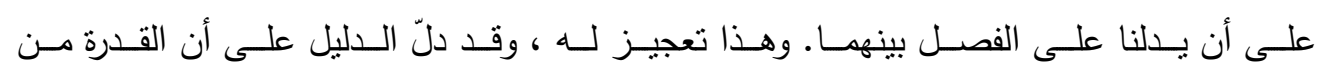

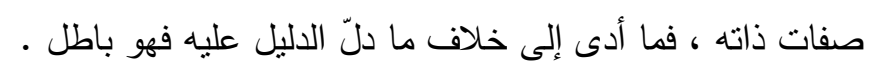

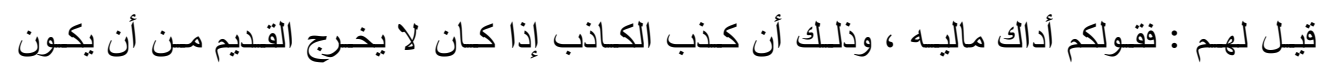

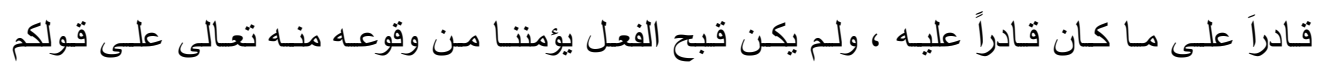

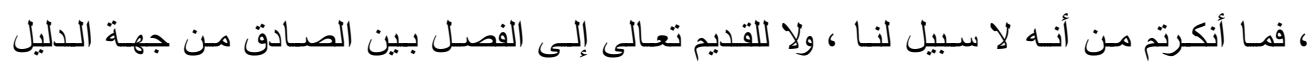

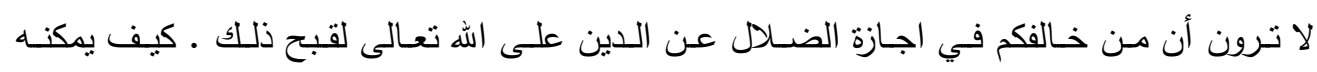

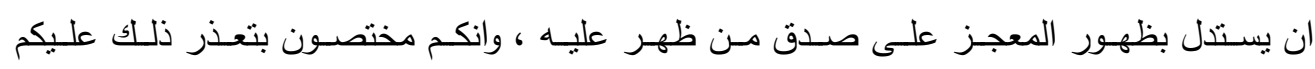

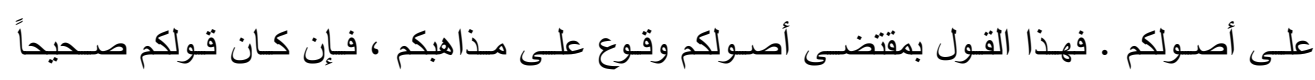

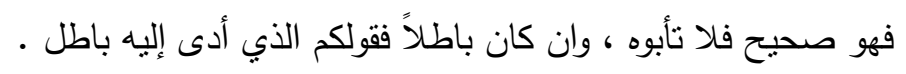




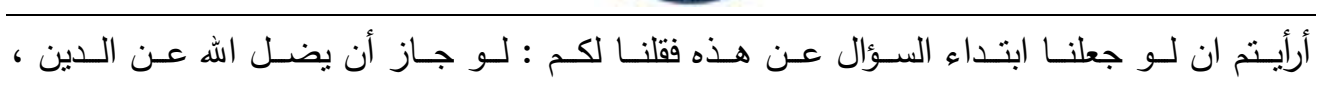

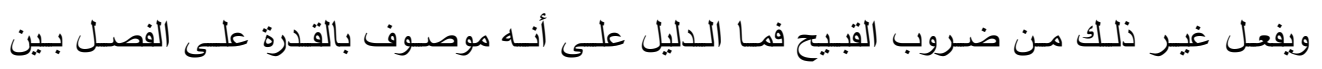

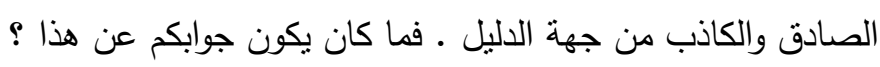

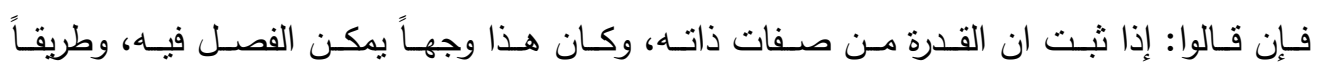

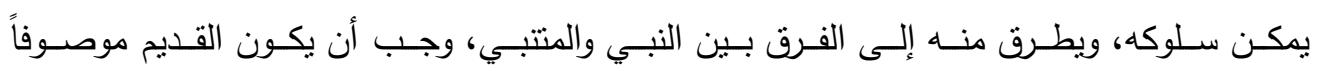

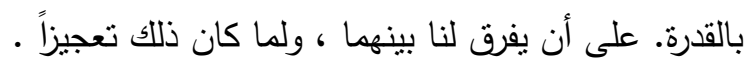

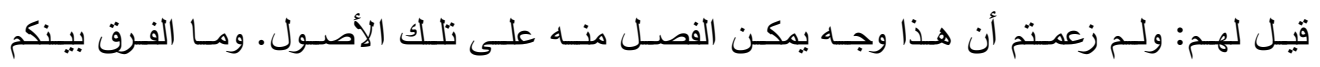

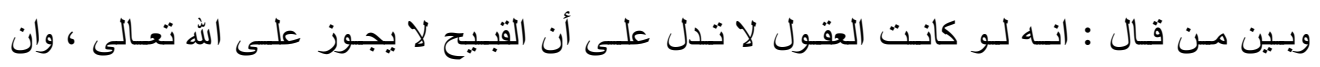

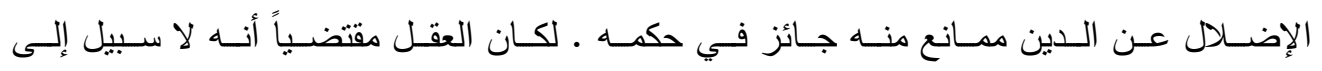

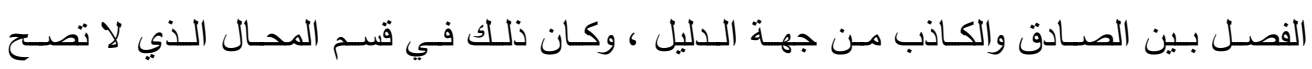

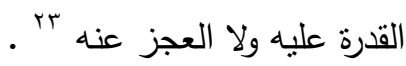

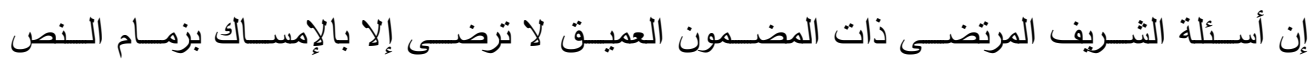

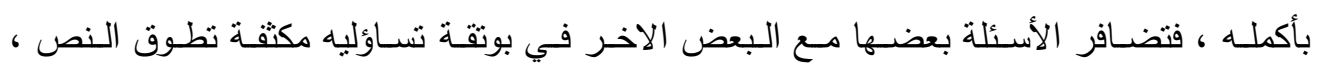

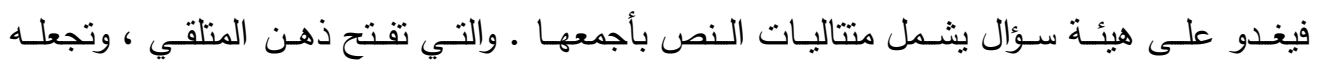

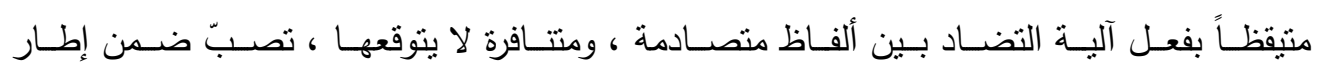

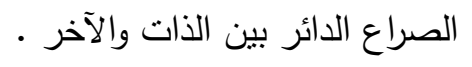

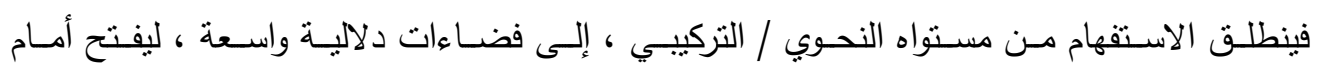

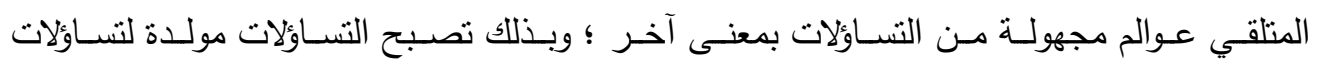

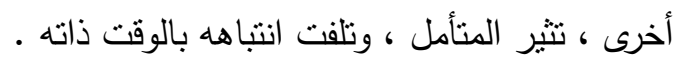

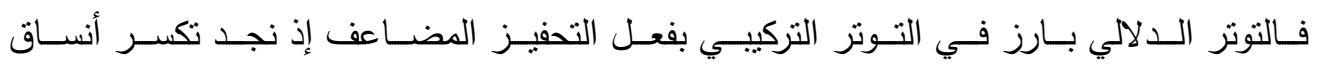

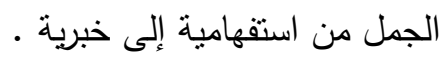




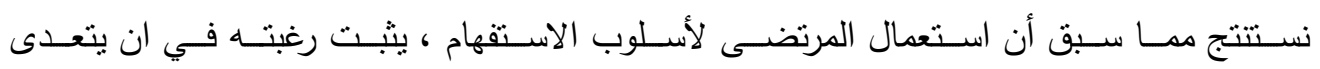

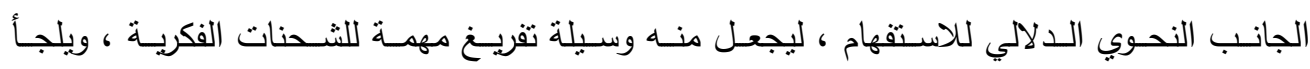
إلى اصطناع تقنية الحوار بوساطة الاستقهام من اجل اشراك المتلقي بالطرح الاسلوبي.

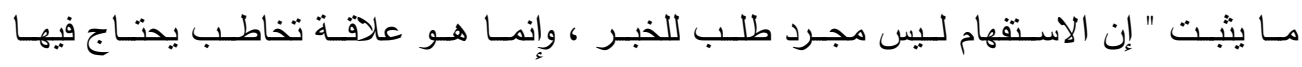

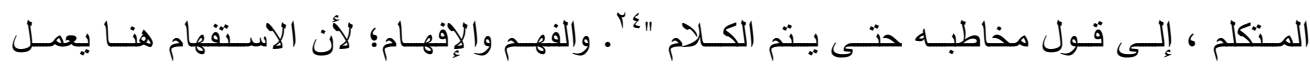

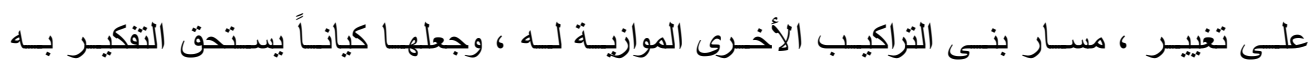

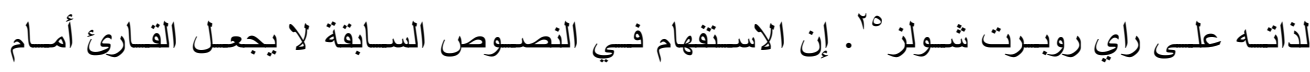

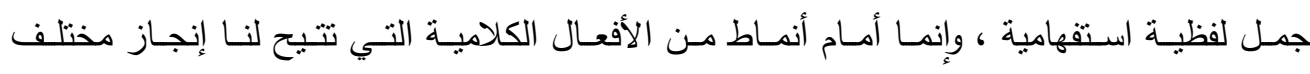
أفعـال الاتصــال ، وهـذه وظيفـة مههـة مـن وظـائف البراغماتيـة اللغويـة ، التـي تشـكل الرسـالة

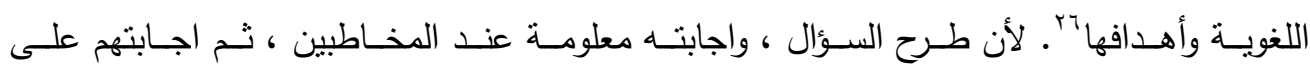

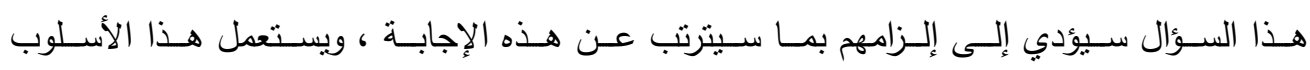
لإقامة الحجة على الخصم ، وإبراز وظيفته البلاغية ثبوتاً أو نفياً .

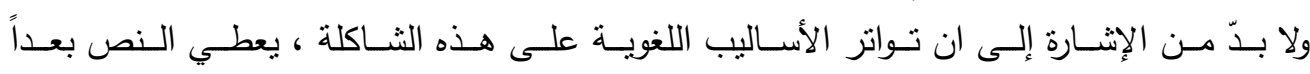

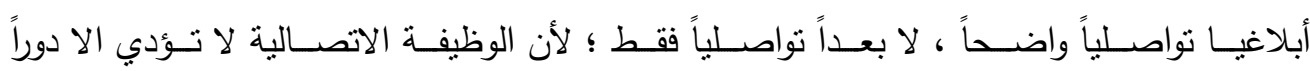

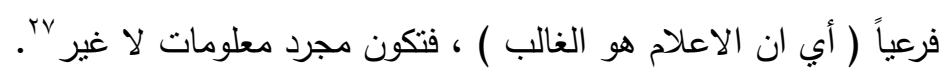

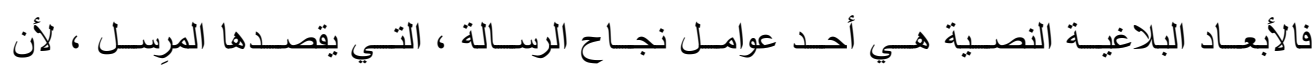

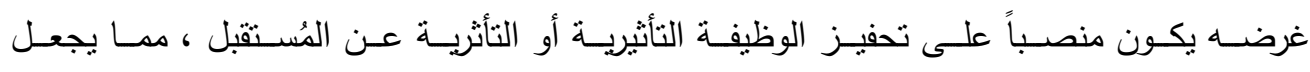

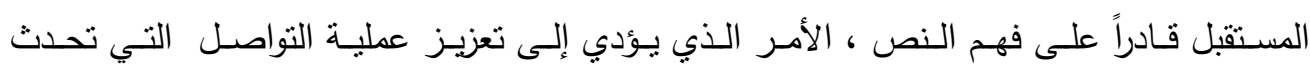

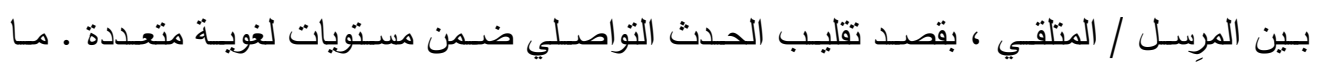

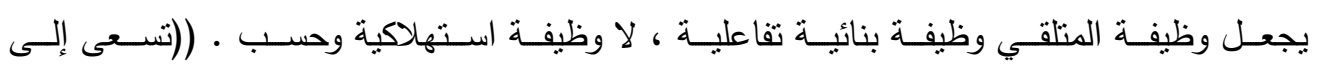

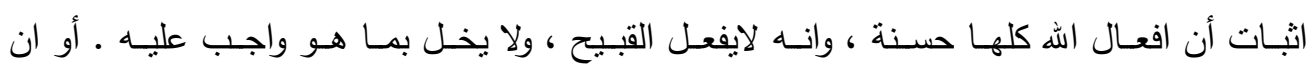
العدل تتزيه الله سبحانه وتعالى عن أمور ثناثة :

أولها :القبائح أجمع ، وثانيها تتزبهه عن ان لا يفعل ما يجب من ثواب وغيره .

وثالثهـا : تتزيهـهـ عـن التعبـد بـالقبيح ، وخـلاف المصـلحة ، واثبـات جميـع أفعالـه حكمـة ،

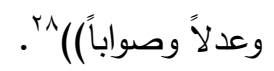




\section{الخاتمة}

وفي ختام بحثنا كانت أهم النتائج التي توصلنا اليها ما يأتي :

- ان إحدى طرق الثريف المرتضى ، في الجل ، ومناقثة الآخرين تقوم على طرح الأسئلة

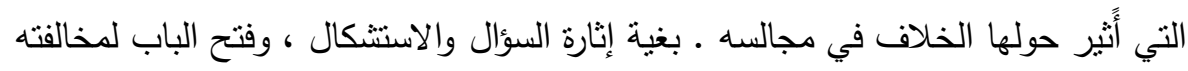

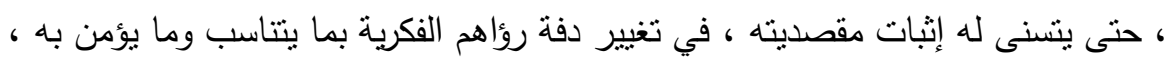

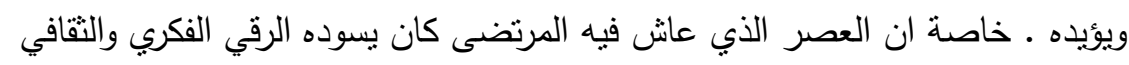

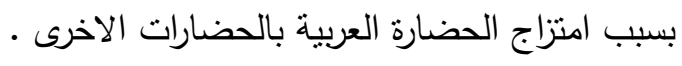

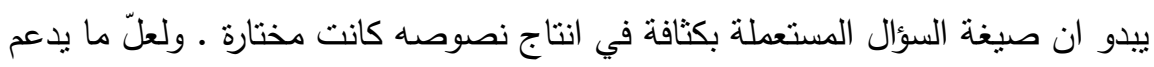

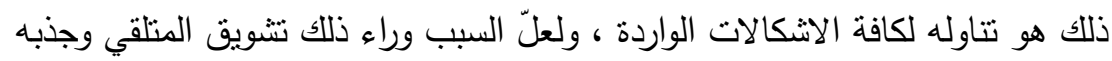

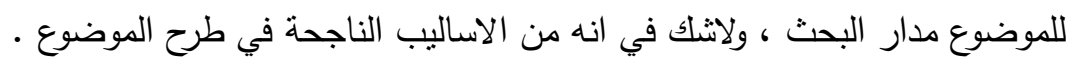

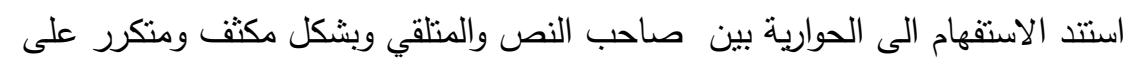

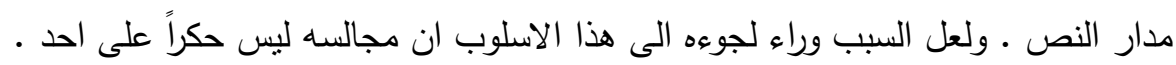

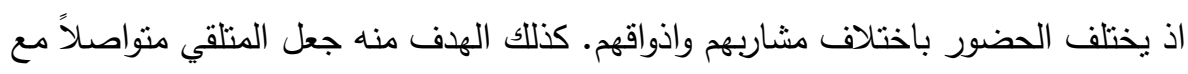

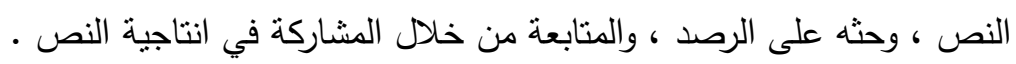

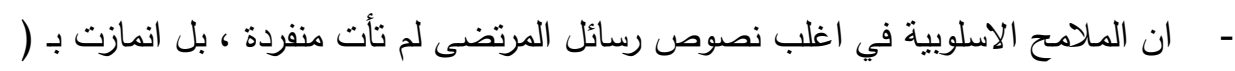

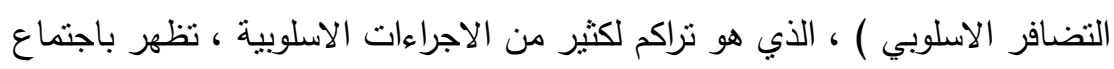

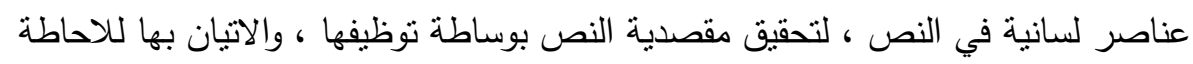

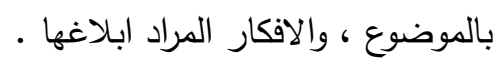




\section{ثبت المصادر والمراجع}

- الإتقان في علوم القرآن ، جلال الدين عبد الرحمن السيوطي ( ت (1/9ه ) ، تحقيق : محمد

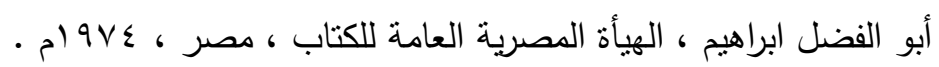

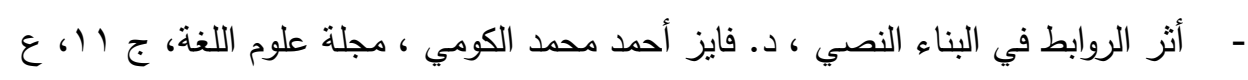
•

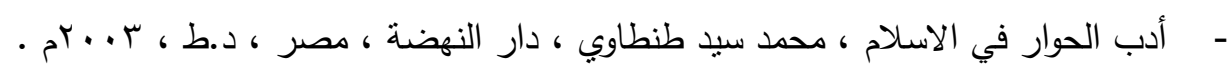

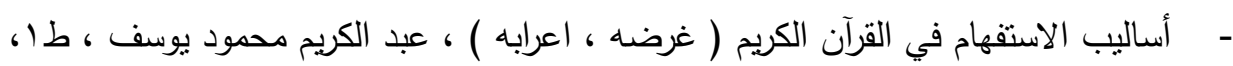

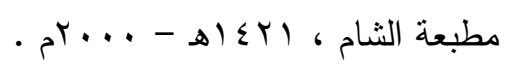

- -

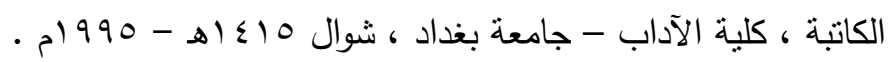

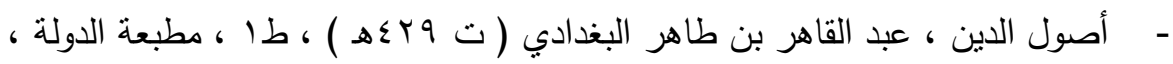

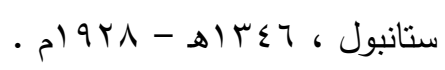

بنية الجملة العربية بين التحليل والنظرية ، عاشور المنصف ، منشورات جامعة تونس،

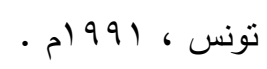

- بنية اللغة الثعرية ، جان كوهن ، ترجمة : محمد الولي ، ومحمد العمري ، طا ، دار توبقال للنشر ، الدار البيضاء ، ضمن سلسلة المعرفة الادبية .

تجليات الحداثة الشعرية في ديوان " البرزخ والسكين " ، للثاعر عبد الله حمادي ، سامية

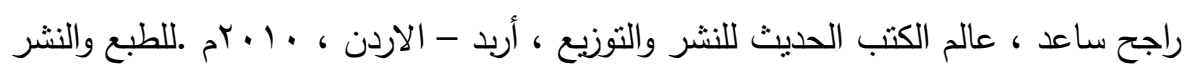
-

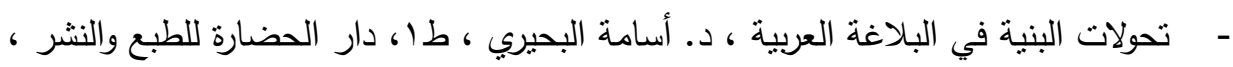

$$
\text { . }
$$

- تحويلات الطلب : ومحددات الدلالة ( مدخل الى تحليل الخطاب النبوي الثربف ) ، د.

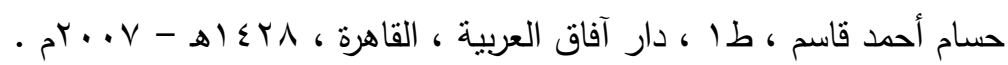
- الرسائل الادبية ودورها في تطوير النثر العربي القديم ( مشروع قراءة شعرية ) ، صالح بن

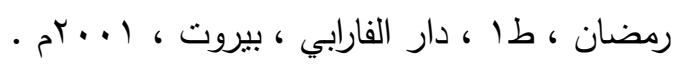


- رسائل الثريف المرتضى ، تقديم واشراف : السيد احمد الحسيني ، اعداد مهدي رجائي ،

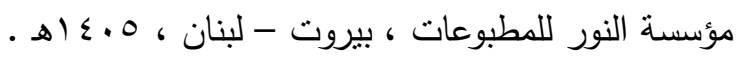
-

$$
\text { منشورات اتحاد كتاب العرب ، دمشق ، } 991 \text { ام . }
$$

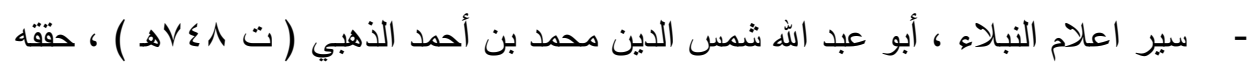
وخرج أحاديثه وعلق عليه ، شعيب الأرنؤوط ، ومحمد نعيم العرقسوسي ، مؤسسة الرسالة

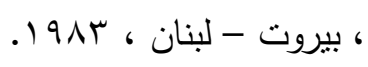

- السيمياء والتأويل ، روبرت شولز ، ترجمة : سعيد الغانمي ، المؤسسة العربية للاراسات

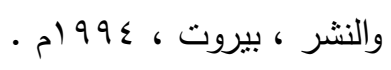

- قراءة جديدة للبلاغة القديمة ، رولان بارت ، نرجمة عمر أوكان ، طا ، روئة للنشر والتوزيع

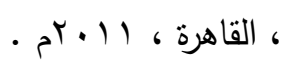

- لسان الميزان ، أحمد بن علي بن حجر العسقلاني ، مطبعة مجلس دائرة المعارف النظامية

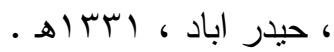

- المختصر في أصول الدين ضمن كتاب " رسائل العدل والتوحيد " ، تحقيق محمد عمارة ،

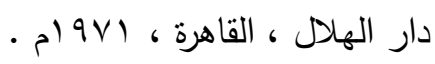

مدخل الى علم اللغة النص ، د يترهانيه ، ترجمة : فالح بن شبيب العجمي ، مطابع جامعة • الملكك سعود ، 999

معجم المصطلحات البلاغية وتطورها ، د. أحمد مطلوب ، طـا، مطبوعات المجمع العلمي

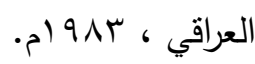
- مقدمة الى علم الدلالة الالسني ، هربرت بركلي ، ترجمة : قاسم المقداد ، طا ، منشورات

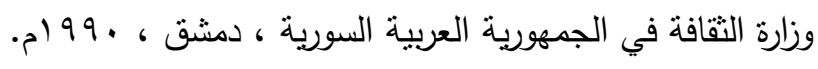
- - منطق النخل ، استدعاءات قرائية في الشعر العراقي الحديث ، د. علي حداد ، منشورات

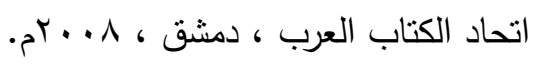

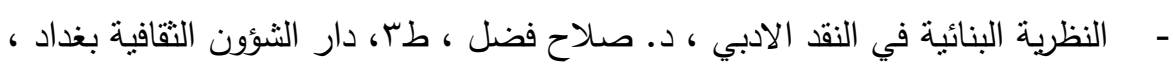


109 : ' بنظر معجم المصطلحات البلاغية ، وتطورها r ب بنظر الرسائل الادبية ، ودورها في تطوير النثر العربي القديم ( مشروع قراءة شعرية ) : 579. ك

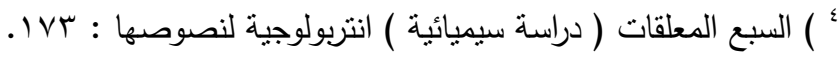
665 الاتقان في علوم القرآن : " ) تجليات الحداثة الشعرية في ديوان " البرزخ والسكين " للشاعر : عبد الله حمادي : 154. .

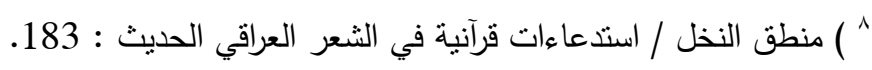

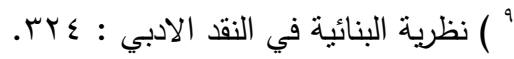

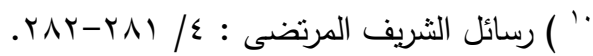

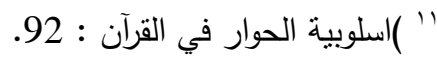

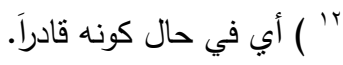

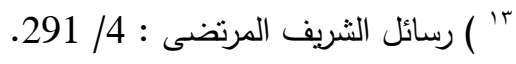

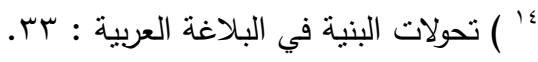

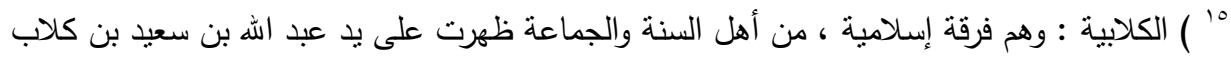
القطان البصري ، في النصف الاول من القرن الثالث الهجري ـ ولقب كلاباً لأنه كان يجتذب الخصم الئ اليه

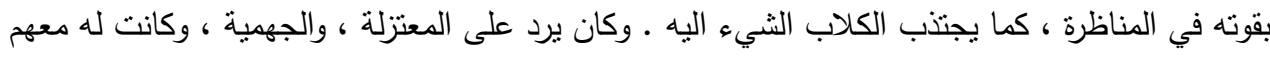

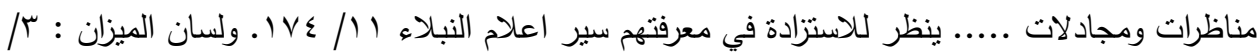

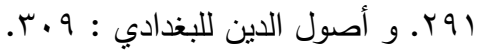

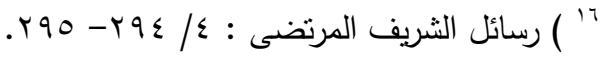

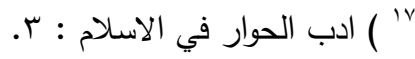

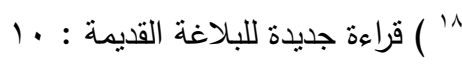

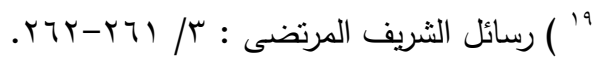

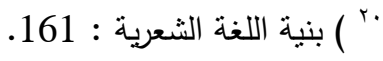

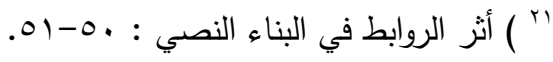

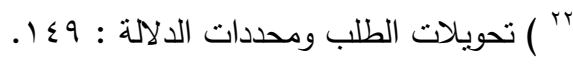

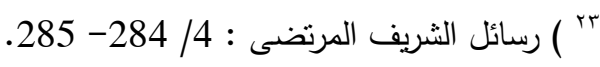


العـــــدد الثــامن عثــر

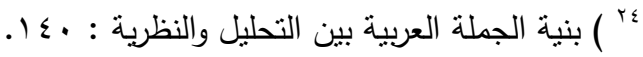

4ro

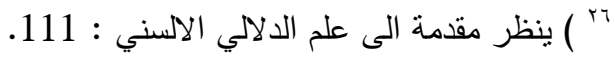

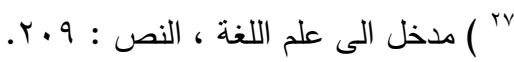

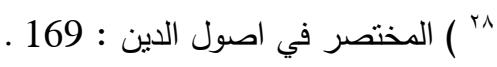

